Article

\title{
Synthesis and Light-Induced Actuation of Photo-Labile 2-Pyridyl-1,2,3-Triazole Ru(bis-bipyridyl) Appended Ferrocene Rotors
}

\author{
James A. Findlay *, Jonathan E. Barnsley, Keith C. Gordon $\mathbb{D}^{\mathbb{D}}$ and James D. Crowley * $\mathbb{D}$ \\ Department of Chemistry, University of Otago, P.O. Box 56, Dunedin 9054, Otago, New Zealand; \\ jono.barnsley@postgrad.otago.ac.nz (J.E.B.); keith.gordon@otago.ac.nz (K.C.G.) \\ * Correspondence: finja479@Student.otago.ac.nz (J.A.F.); jcrowley@chemistry.otago.ac.nz (J.D.C.); \\ Tel.: +64-3-479-7731 (J.D.C.)
}

Received: 28 July 2018; Accepted: 9 August 2018; Published: 14 August 2018

\begin{abstract}
To realise useful control over molecular motion in the future an extensive toolbox of both actionable molecules and stimuli-responsive units must be developed. Previously, our laboratory has reported 1,1'-disubstituted ferrocene $(\mathrm{Fc})$ rotor units which assume a contracted $/ \pi$-stacked conformation until complexation of cationic metal ions causes rotation about the Ferrocene ( $\mathrm{Fc})$ molecular 'ball-bearing'. Herein, we explore the potential of using the photochemical ejection of $\left[\mathrm{Ru}\left(2,2^{\prime} \text {-bipyridyl }\right)_{2}\right]^{2+}$ units as a stimulus for the rotational contraction of new ferrocene rotor units. Fc rotors with both 'regular' and 'inverse' 2-pyridyl-1,2,3-triazole binding pockets and their corresponding $\left[\mathrm{Ru}\left(2,2^{\prime} \text {-bipyridyl }\right)_{2}\right]^{2+}$ complexes were synthesised. The rotors and complexes were characterised using nuclear magnetic resonance (NMR) and ultraviolet (UV)-visible spectroscopies, Electro-Spray Ionisation Mass Spectrometry (ESI-MS), and electrochemistry. The 1,1'-disubstituted Fc ligands were shown to $\pi$-stack both in solution and solid state. Density Functional Theory (DFT) calculations (CAM-B3LYP/6-31G(d)) support the notion that complexation to $\left[\mathrm{Ru}\left(2,2^{\prime} \text {-bipyridyl }\right)_{2}\right]^{2+}$ caused a rotation from the syn- to the anti-conformation. Upon photo-irradiation with UV light $(254 \mathrm{~nm})$, photo-ejection of the $\left[\mathrm{Ru}\left(2,2^{\prime} \text {-bipyridyl }\right)_{2}\left(\mathrm{CH}_{3} \mathrm{CN}\right)_{2}\right]^{2+}$ units in acetonitrile was observed. The re-complexation of the $\left[\mathrm{Ru}\left(2,2^{\prime} \text {-bipyridyl }\right)_{2}\right]^{2+}$ units could be achieved using acetone as the reaction solvent. However, the process was exceedingly slowly. Additionally, the Fc ligands slowly decomposed when exposed to UV irradiation meaning that only one extension and contraction cycle could be completed.
\end{abstract}

Keywords: photochemical ligand-ejection; ruthenium(II) photo-ejection; light-induced molecular motion; molecular switches; nanotechnology

\section{Introduction}

Exploring stimuli controlled motion in synthetic molecules will lead to advances in nanotechnology, and as such, molecular switches and machines have received increasing attention over recent years [1-6]. Relatively simple components, such as reversibly extendable/contractible units, using a stimulus as ubiquitous as light, could form useful components of larger assemblies. Many classes of molecular switches and machines have been realised, with molecular motion induced by a range of stimuli including chemical [7-9], electrochemical [10-12], and photochemical inputs [13-15]. Light-induced processes are particularly attractive as the input may be considered a clean energy source with excellent spatial resolution, and as such, photoactivated switching has been a focus of many research groups [16-21]. Some of the most notable examples of this subclass of molecular machines are those of Feringa and co-workers. They have developed a series of overcrowded alkenes 
which undergo unidirectional rotation through consecutive photo-induced isomerisation and thermal relaxation processes [22-25]. Examples of light-induced linear and rotational motion in rotaxanes and catenanes have been reported [26]. The photo-activated motion within these mechanically interlocked molecules, (MIMs), uses either the photoisomerisation of molecular recognition sites [27,28] or photo-induced redox processes (often through the use of a photosensitiser) to alter the preferred interaction between a macrocycle and the molecular fragment from which it is mechanically inseparable. The majority of the systems developed to date are built from mainly organic components. However, there are a few in which photoactive metals complexes are exploited to generate the molecular motion [29]. Of note is work of Sauvage and co-workers who have reported copper(I)/copper(II) photo-oxidation switches [30,31], but more relevantly have also generated a significant amount of work around photo-induced ligand ejection from ruthenium(II) ions [32-35].

The most commonly investigated metal ion for photo-induced ligand ejection is $\mathrm{Ru}(\mathrm{II})$, although examples involving osmium(II) complexes have been reported [36]. Photo-induced ligand-ejection from ruthenium(II), which is usually considered to form inert coordination bonds, has been recently studied for medicinal applications, with a number of reports developing prodrugs which undergo photo-ligand ejection, towards 'switch-on cytotoxicity' type technology to fight diseases such as cancer [37-42]. However, other potential applications have been investigated [43], including photo-induced self-assembly [44], and molecular motion [45]. There are two main strategies used when designing bidentate ligands for the purpose of photo-ejection from $\left[R u(L)_{2}\right]^{2+}$ (where $\mathrm{L}$ is a bidentate $\mathrm{N}-\mathrm{N}$ donor ligand) type units: One is to create a sterically encumbered coordination environment, often by adding functionalities in the ortho positions of coordinating pyridyl donors [32,40,46,47]. The other is to simply create a ligand with weaker donor capability [48]. It has been shown bidentate ligands of the 2-pyridyl-1,2,3-triazole (pytri) or the bis-triazolyl type are suitable for this purpose as 1,2,3-triazole rings possess a weaker donor ability than pyridine [49-51].

While there are reports of materials, such as nanoparticles [52] and polymers [53-55], able to undergo expansion/contraction type motion upon application of a light stimulus, the literature is lacking in photo-induced expansion/contraction type mechanical motions of discrete molecules. Ferrocene $(\mathrm{Fc})$ has been exploited as a molecular 'ball-bearing', because the two cyclopentadienyl (cp) rings are able to rotate about the iron centre. One can envisage substituents of the cp rings of an Fc unit being reversibly brought together and repelled through use of one or more stimuli. There are examples of rotatable ferrocene switches controlled by hydrogen bonding [56,57], chloride ions [58], metal ion coordination [59], and electrochemistry [60]. Previously our lab reported [61,62] the electrochemically driven expansion and contraction of Fc based molecular actuators/'folding rulers'. The switching mechanism used in both of these systems exploits the switching system developed by Sauvage and Schmittel and co-workers [31,63-66]. Both ferrocene rotors bear 2,2'-bipyridine chelators able to bind $\mathrm{Cu}(\mathrm{I})$ ions in heteroleptic tetrahedral complexes with bulky 6,6'-dimesityl-2,2'-bipyridine ligands. This forms the extended state of the Fc rotors as the bulk of the co-ligands require rotation about the Fc units. Oxidation to $\mathrm{Cu}$ (II) alters the coordination tendency of the metal ion such that it de-complexes from the Fc rotors to bind to terpy ligands present in solution. This allows the Fc rotors to re-establish their native $\pi-\pi$ stacked contracted conformations.

Herein, we explore the potential of bis-(2,2'-bipyridyl)-ruthenium(II) $\left(\left[\operatorname{Ru}(\text { bipy })_{2}\right]^{2+}\right)$ units as a stimulus to cause extension within new bis-bidentate pytri $F_{C}$ ligands from their native syn $\pi-\pi$ stacked conformational state, and the reverse process of photo-ejection of the $\left[R u(b i p y)_{2}\right]^{2+}$ units. Two different structural isomers of bidentate pytri binding pockets, namely 'regular (reg)' and 'inverse (inv)' pytri ligands were decided upon as likely photo-labile candidates as we have previously shown that $[\mathrm{Ru} \text { (bipy)(inv-pytri) }]^{2+}$ complexes would photo-eject the inv-pytri ligands when exposed to UV irradiation in acetonitrile [49]. The 'inverse' pytri structural isomers are weaker chelators than their 'regular' analogues as the nitrogen donor in the 2-position of the 1,2,3-triazole is less electron rich [49]. We have synthesised two new Fc containing inv-pytri ligands (L2 and L4) to form a small family with two reg-pytri analogues (L1 and L3, Figure 1), previously reported by us [67]. The corresponding 
model [Ru(pytri)(bipy) $\left.)_{2}\right]\left(\mathrm{BF}_{4}\right)_{2}$ complexes $\mathbf{L 1 R u}$ and $\mathbf{L} \mathbf{2 R \mathbf { u }}$ were generated from the model ligands $\mathbf{L 1}$ and L2. The extended tetra-cationic rotor complexes $\mathbf{L} 3 \mathbf{R} \mathbf{u}$ and $\mathbf{L} 4 \mathbf{R} \mathbf{u}$ were then generated from the Fc rotor ligands $\mathbf{L} 3$ and $\mathbf{L} 4$. The four $\mathrm{Ru}(\mathrm{II})$ complexes were characterised using nuclear magnetic resonance (NMR), infrared (IR), and ultraviolet (UV)-visible absorption spectroscopies, along with electro-spray ionisation mass spectrometry (ESI-MS) and electrochemical investigations. Additionally, irradiation of the four Ru(II) complexes in acetonitrile solution with UV-light (254 nm) was shown to liberate $\left[\mathrm{Ru}(\text { bipy })_{2}\left(\mathrm{CD}_{3} \mathrm{CN}\right)_{2}\right]\left(\mathrm{BF}_{4}\right)_{2}$, as shown through ${ }^{1} \mathrm{H} \mathrm{NMR}$ spectroscopy and ESI-MS. Thermal re-coordination of the Ru(II) fragment(s) to complete the switching cycle was then attempted. However, the reverse process could not be completed because the Fc ligand decomposed during the photo-ejection process.

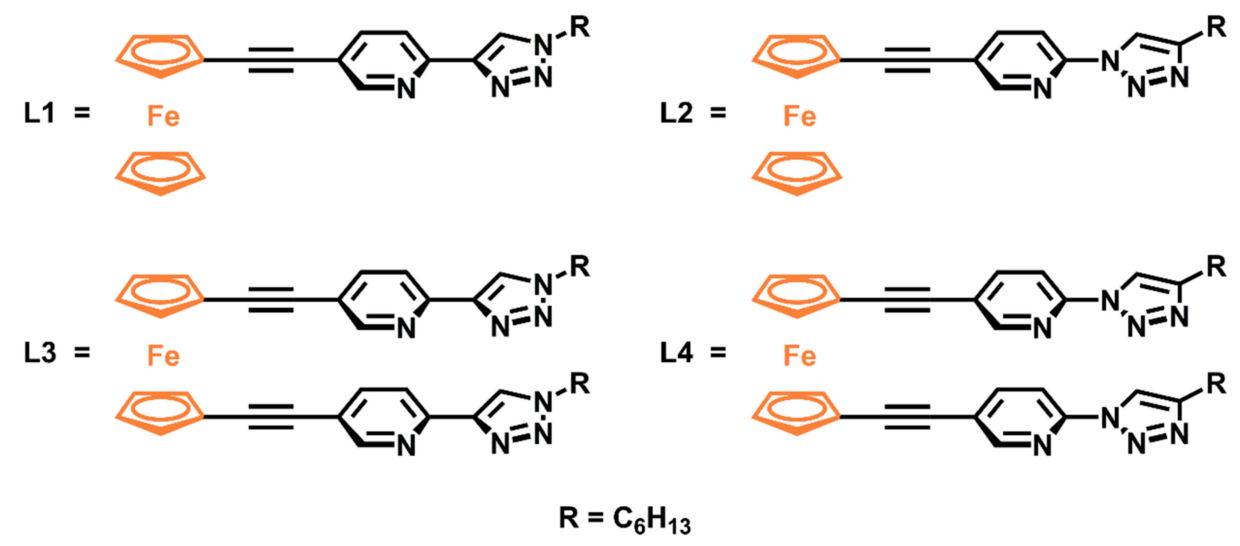

Figure 1. The molecular structures of ferrocene model (L1-L2) and rotor ligands (L3-L4).

\section{Results}

\subsection{Synthesis of Ligands and $R u(I I)(\text { bipy })_{2}$ Complexes}

Ligands L1-L4 (Figure 1) were all synthesised using Pd(0)-catalysed Sonogashira cross coupling and $\mathrm{Cu}(\mathrm{I})$ catalysed azide-alkyne cyclo addition ( $\mathrm{CuACC}$ ) protocols. The syntheses of new ligands L2 and L4 are shown in the Supplementary Material (Schemes S1 and S2), along with full experimental procedures for all previously unreported intermediates. $\mathbf{L} \mathbf{1}-\mathbf{L} 4$ were characterised by ${ }^{1} \mathrm{H}$ NMR spectroscopy, ${ }^{13} \mathrm{C}$ NMR spectroscopy, ESI-mass spectrometry, elemental analysis, UV-visible spectroscopy, and in the cases of L2 and L4, X-ray crystallography (see Supplementary Material). Comparision of the ${ }^{1} \mathrm{H}$ NMR spectra of the model ligand with the rotor systems indicated that the Fc rotor based switches (L3 and L4) adopt a $\pi-\pi$ stacked syn-conformation in solution. As shown in Figure 2, the ${ }^{1} \mathrm{H}$ NMR signals of the aromatic binding pockets of the disubstituted Fc ligands are shifted up-field relative to the corresponding signals in the model ligands, indicative of $\pi-\pi$ interactions.
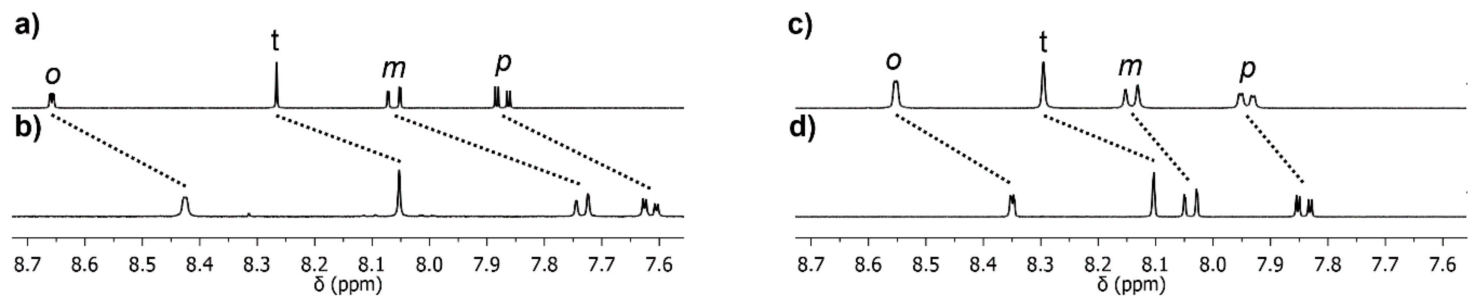

Figure 2. Partial stacked ${ }^{1} \mathrm{H}$ nuclear magnetic resonance (NMR) spectra (400 MHz, $\left.298 \mathrm{~K}\right)$ of: (a) L1, and (b) $\mathbf{L} 3\left(\mathrm{CD}_{3} \mathrm{CN}\right)$, and (c) $\mathbf{L} 2$, and (d) $\mathbf{L} 4\left(\mathrm{CDCl}_{3}\right)$; labels refer to ortho, meta, and para pyridyl and the triazole, $t$, signals of the ligands. 
The solid-state structures of L2 and L4 (Figure 3) show in both cases the Fc units exhibit the expected eclipsed conformation of the cyclopentadienyl rings. The aromatic pytri binding pockets of L4 are also $\pi-\pi$ stacked (pyridine-pyridine centroid distance $=3.58 \AA$, tri-tri centroid distance $3.913 \AA$ and the angle between the ferrocene substituents $=6.58^{\circ}$, (see Supplementary Material, Figure S53), providing further support for the contracted syn conformation of the disubstituted Fc ligands in their native state.

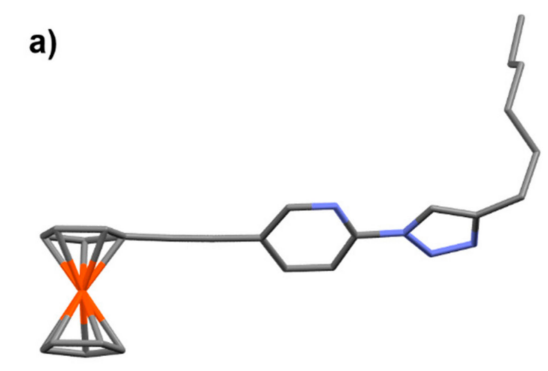

b)

c)
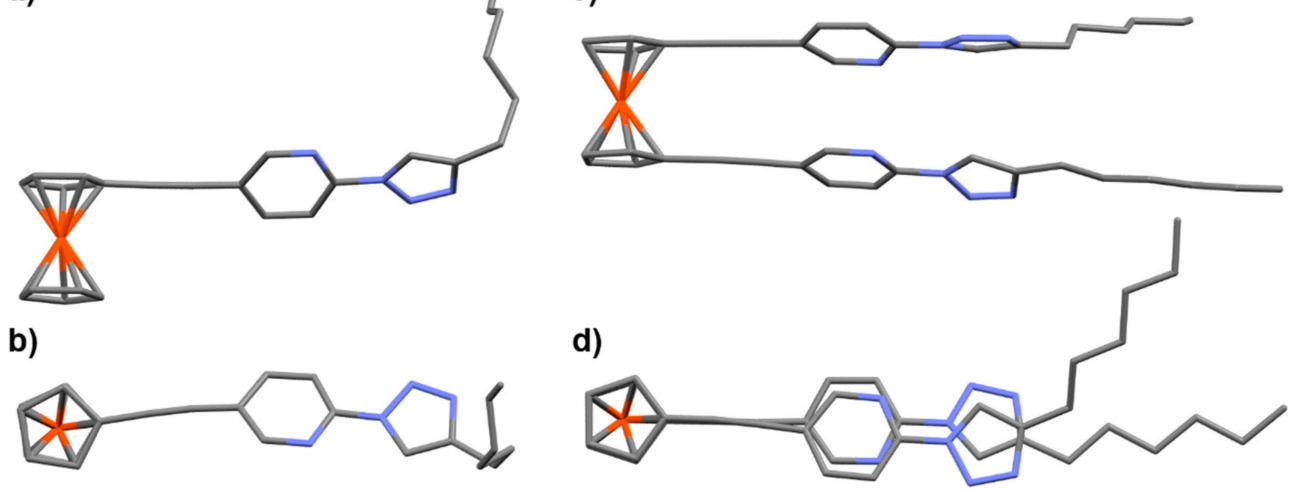

Figure 3. Depiction of the solid state structures of L2 and L4; (a) L2 side view, (b) L2 top view, (c) L4 side view, (d) L4 top view. Hydrogen atoms omitted for clarity.

The synthesis of the $\left[\mathrm{Ru}(\text { bipy })_{2}\right]^{2+}$ complexes of each of $\mathbf{L 1}-\mathbf{L} \mathbf{4}$ (Figure 4) was achieved by first generating $\left[\mathrm{Ru}(\text { bipy })_{2}(\text { acetone })_{2}\right]\left(\mathrm{BF}_{4}\right)_{2}$ by stirring $\left[\mathrm{Ru}(\text { bipy })_{2}(\mathrm{Cl})_{2}\right]$ and two equivalents of $\mathrm{AgBF}_{4}$ in acetone. Refluxing this $\mathrm{Ru}(\mathrm{II})$ reactive intermediate with each of $\mathbf{L 1}-\mathbf{L} 4$ in acetone gave the desired di- (L1-L2) and tetra-cationic (L3-L4) complexes in good yields (74-94\%). L1Ru-L4Ru were all characterised by ${ }^{1} \mathrm{H}$ NMR spectroscopy, ESI-mass spectrometry, elemental analysis and UV-visible spectroscopy. The ${ }^{1} \mathrm{H}$ NMR spectra of $\mathbf{L} 1 \mathbf{R} \mathbf{u}-\mathbf{L} 4 \mathbf{R u}$ all showed downfield shifts of the ligand signals, most notably the large downfield shift of the triazole signal in all cases, indicative of complexation to $\mathrm{Ru}(\mathrm{II})$ (Supplementary Material). Furthermore, the two symmetric Fc cyclopentadienyl signals in the ${ }^{1} \mathrm{H}$ NMR of both $\mathbf{L} 3$ and $\mathbf{L} 4$ are replaced by a more complicated set of signals in the ${ }^{1} \mathrm{H}$ NMR of $\mathbf{L} 3 \mathbf{R} \mathbf{u}$ and $\mathbf{L} 4 \mathbf{R u}$, presumably due to the different isomeric mixtures expected with respect to the $\mathrm{Ru}$ (II) centres $(\Delta / \Delta, \Delta / \Lambda$, and $\Lambda, \Lambda)$. Diffusion-ordered ${ }^{1} \mathrm{H}$ NMR spectroscopy (DOSY NMR) was used to further confirm the numerous signals in the aromatic regions of the ${ }^{1} \mathrm{H}$ NMR spectra of $\mathbf{L} 1 \mathbf{R u}-\mathbf{L} 4 \mathbf{R} \mathbf{u}$ were, indeed, diffusing at the same rate, thus, belonging to species of the same molecular weight (Supplementary Material). Interestingly the aromatic signals in the ${ }^{1} \mathrm{H}$ NMR spectrum of L3Ru suggested the presence of two isomers (or two NMR equivalent pairs of isomers) in equal proportion, however, the same was not observed in the spectrum of $\mathbf{L} 4 \mathbf{R} \mathbf{u}$ which displays a fully symmetric spectrum. Despite the potential for different isomeric mixtures $(\Delta / \Delta, \Delta / \Delta$, and $\Lambda, \Lambda)$, the DOSY and mass spectral data support only one molecular weight being present in each case (Supplementary Material).

Density Functional Theory (DFT) calculations (see the Supplementary Material for the details of the computational methods) were performed to support the notion the rotor complexes L3Ru and L4Ru must adopt an extended anti-conformation. The optimised open structure (dihedral angle $\approx \pm 180^{\circ}$ ) was observed to be the lowest energy conformation for both complexes (Figure 5 and Supplementary Material, Figures S55-S62). As the dihedral angle is decreased, the relative energy increases (see Figure S54). In the ranges of $\pm 180^{\circ}$ to $\pm 110^{\circ}$ the relative energy is within $5 \mathrm{~kJ} \mathrm{~mol}^{-1}$, and according to the Boltzmann distribution, will be accessible at room temperature. Dihedral angles of $\pm 80^{\circ}\left(>7 \mathrm{~kJ} \mathrm{~mol}^{-1}\right)$ or higher become energetically disfavoured, with populations of less than $6 \%$, according to the Boltzmann distribution. This energy scan indicates that the $\pm 180^{\circ}$ to $\pm 110^{\circ}$ range will 
be most vastly populated, and smaller dihedral angles will be disfavoured. Thus, when the Fc rotors (L3 and L4) are uncomplexed, a syn-stacked conformation is preferred. However, complexation to the $\left[\mathrm{Ru}(\text { bipy })_{2}\right]^{2+}$ units causes a switch to an anti-extended conformation presumably the switching is driven by a combination of charge repulsion between the $\mathrm{Ru}(\mathrm{II})$ ion and destabilising steric interactions.

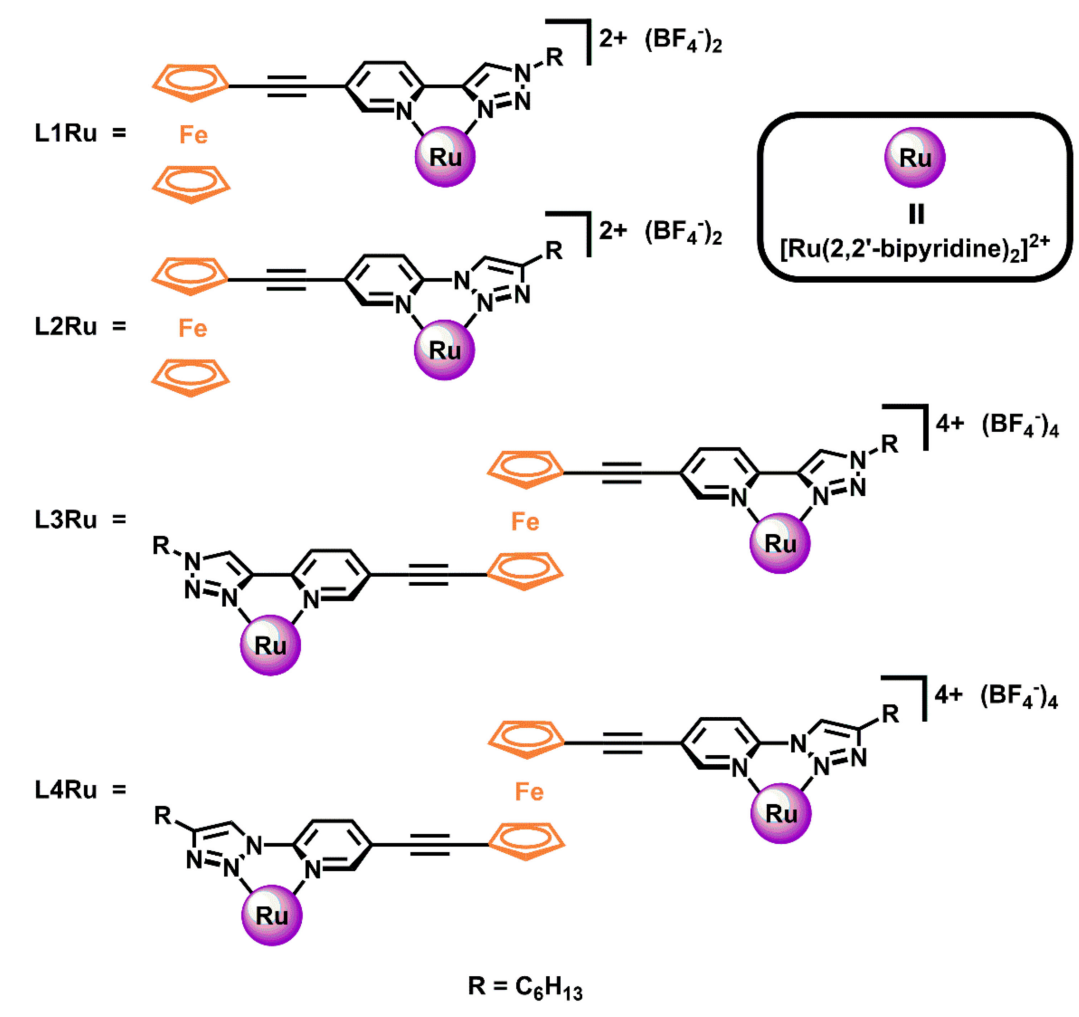

Figure 4. The molecular structures of the ruthenium complexes $\mathbf{L} 1 \mathbf{R u}-\mathbf{L} 4 \mathbf{R u}$.

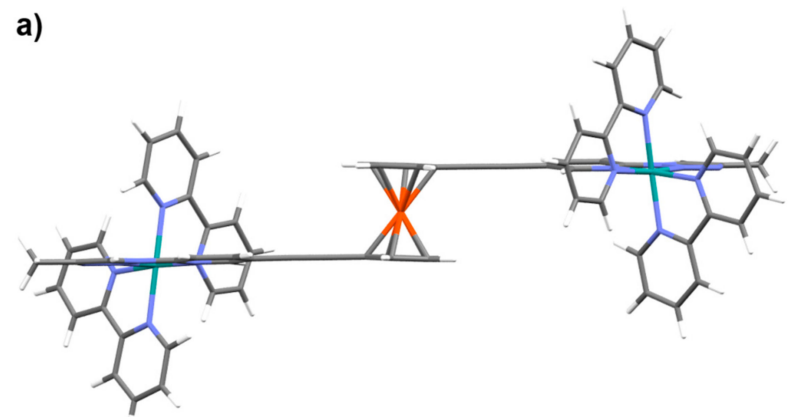

b)

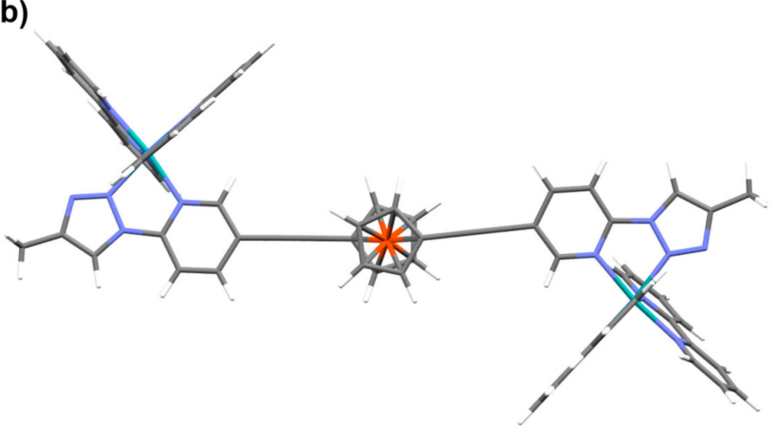

Figure 5. Density Functional Theory (DFT) (CAM-B3LYP, 6-31G(d)) optimised structure of L4Ru (dihedral $\approx 180^{\circ}$ ) with (a) side view and $(\mathbf{b})$ top view. 


\subsection{UV-Visible Spectroscopy}

The UV-Visible spectra of all ligands (L1-L4) and complexes $(\mathbf{L} 1 \mathbf{R} \mathbf{u}-\mathbf{L} 4 \mathbf{R} \mathbf{u})$ were recorded in dichloromethane (DCM) solution (Figure 6 and Supplementary Material, Figures S38 and S39). In the electronic absorption spectra of the ligands, the features of note are the $\pi-\pi^{*}$ transitions around 310 and $370 \mathrm{~nm}$, and the transition at around $450 \mathrm{~nm}$ which is assigned as an Fc based process [68,69]. In the spectra of the complexes, convoluted absorbance features between 400 and $470 \mathrm{~nm}$ are observed (along with shoulder features at around $500 \mathrm{~nm}$ ) and are assigned as Ru based Metal-to-Ligand Charge Transfer (MLCT) transitions. For L1Ru and L2Ru, the extinction coefficient(s) for these transitions are $\sim 10$ and $\sim 13 \times 10^{3} \mathrm{~L} \mathrm{~mol}^{-1} \mathrm{~cm}^{-1}$ (at 422 and $428 \mathrm{~nm}$ ) respectively. Likewise, for L3Ru and L4Ru, extinction coefficients of $\sim 24$ and $\sim 26 \times 10^{3} \mathrm{~L} \mathrm{~mol}^{-1} \mathrm{~cm}^{-1}$ (at 422 and $427 \mathrm{~nm}$ ) are observed respectively. The ratio of $\mathbf{R u}(\mathrm{II})$ ions to Fc units (1:1 for $\mathbf{L} 1 \mathbf{R} \mathbf{u}$ and $\mathbf{L} 2 \mathbf{R u}$, and 2:1 for $\mathbf{L} 3 \mathbf{R} \mathbf{u}$ and $\mathbf{L} 4 \mathbf{R u}$ ) correlates with the approximate two-fold increase in the intensity of the transition(s) assigned to ruthenium-based MLCT transitions. The UV-Visible absorption spectra of $\mathbf{L 1 R} \mathbf{u}-\mathbf{L} 4 \mathbf{R} \mathbf{u}$ were also recorded in acetonitrile (see Supplementary Material, Figure S40) and differ little to the spectra recorded in DCM.

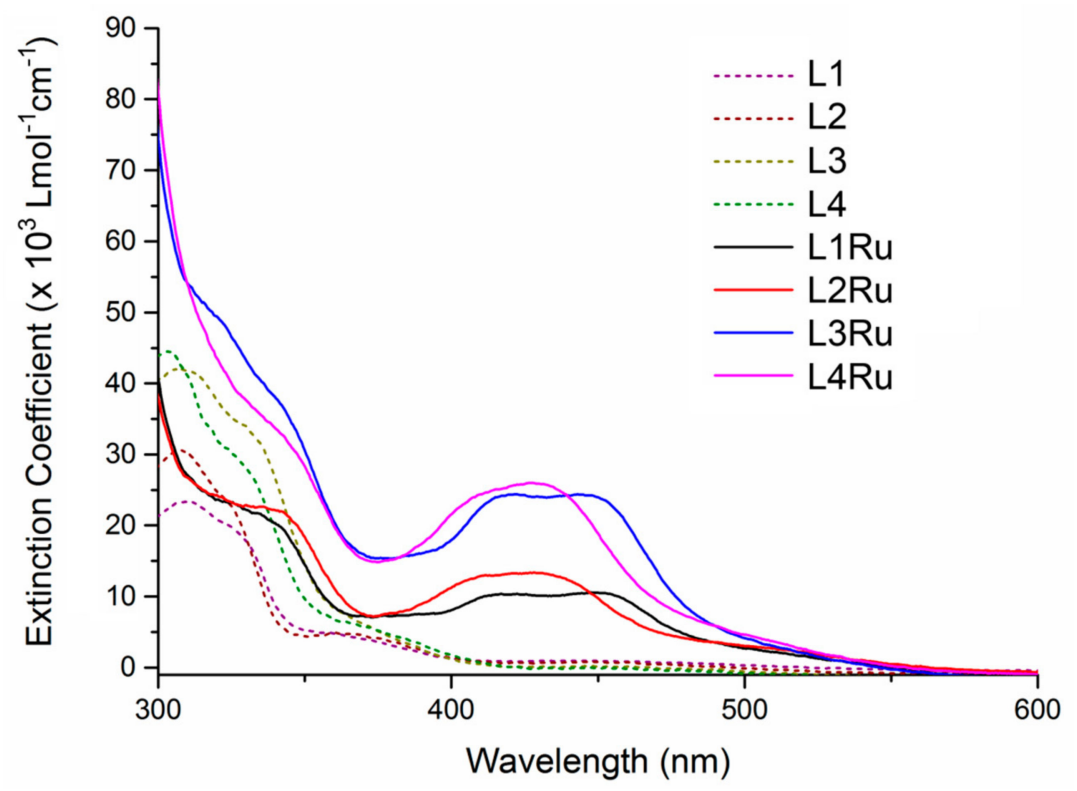

Figure 6. Overlaid UV-Visible spectra of $\mathbf{L 1}-\mathbf{L} 4$ and $\mathbf{L 1 R u}-\mathbf{L} 4 \mathbf{R u}$ recorded in dichloromethane solution $\left(\sim 10^{-5} \mathrm{molL}^{-1}, 298 \mathrm{~K}\right)$.

\subsection{Electrochemistry}

Cyclic and Differential Pulse Voltammetry (CV and DPV) experiments were carried out on $1 \mathrm{mM}$ dichloromethane (DCM) solutions of $\mathbf{L 1}-\mathbf{L} \mathbf{4}$ and the corresponding ruthenium complexes (L1Ru-L4Ru), with $0.1 \mathrm{M} \mathrm{Bu}_{4} \mathrm{NPF}_{6}$ as supporting electrolyte. Cyclic voltammograms for all eight species, with inset DPV plots, can be found in the Supplementary Material (Figures S30-S37), and the half cell potential $\left(\mathrm{E}^{\circ}\right)$ for all observed processes in Table 1 below. The current and potential observed for all processes were reproducible over multiple cycles. L1-4 displayed the expected $\mathrm{Fc}^{+} / \mathrm{Fc}_{\mathrm{c}}$ couple between 0.62 and $0.75 \mathrm{~V}$. The two ferrocenyl oxidation potentials for the mono-substituted ligands are slightly lower than those displayed by the di-substituted ligands (Table 1). All four of L1Ru-L4Ru displayed the $\mathrm{Fc}^{+} / \mathrm{Fc}$ couple along with a $\mathrm{Ru}^{\mathrm{III} / \mathrm{II}}$ couple and two reduction processes assigned to the two bipy ligands on each $\mathrm{Ru}(\mathrm{II})$ centre. As displayed by the ligands, the ferrocenyl based oxidation process occurs at a lower potential in the mono-nuclear complexes versus the di-nuclear analogues. As expected, the current response for the $\mathrm{Ru}^{\mathrm{III} / \mathrm{II}}$ couple is larger for $\mathbf{L} 3 \mathbf{R u}$ and $\mathbf{L} \mathbf{R} \mathbf{R} \mathbf{u}$ versus $\mathbf{L 1 R u}$ and L2Ru, consistent with the molecular formulae. The ruthenium based oxidation process occurs at a 
higher potential in the 'inverse' pytri complexes (L2Ru and L4Ru) than in the 'regular' pytri analogues, similar to previously reported related compounds [49]. Furthermore, both bipy reduction processes are also shifted to the anodic potential in the 'inverse' analogues, relative to the 'regular'. Reduction processes for the pytri ligands were not observed under the conditions employed here within the solvent window.

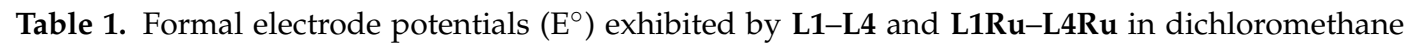
(DCM) solution.

\begin{tabular}{|c|c|c|c|c|}
\hline \multirow[b]{2}{*}{ Compound } & \multicolumn{4}{|c|}{$\mathrm{E}^{\circ}(\Delta \mathrm{E})(\mathrm{V}(\mathrm{mV}))^{\mathrm{a}}$} \\
\hline & Bipy $1^{(0 /-)}$ & Bipy $2^{(0 /-)}$ & $\mathrm{Fc}^{(+/ 0)}$ & $\mathbf{R u} \mathbf{u}^{(\mathrm{III} / \mathrm{II})}$ \\
\hline L1 & - & - & $0.63(88)$ & - \\
\hline L2 & - & - & $0.62(86)$ & - \\
\hline L3 & - & - & $0.69(90)$ & - \\
\hline L4 & - & - & $0.75(84)$ & - \\
\hline L1Ru & $-1.51(150)$ & $-1.22(80)$ & 0.69 (79) & $1.51(110)$ \\
\hline L2Ru & $-1.38(150)$ & $-1.14(86)$ & $0.70(76)$ & $1.60^{\mathrm{b}}$ \\
\hline L3Ru & $-1.50(200)$ & $-1.21(84)$ & $0.83(72)$ & $1.48(84)$ \\
\hline L4Ru & $-1.41(200)$ & $-1.15(120)$ & $0.83(88)$ & $1.57(170)$ \\
\hline
\end{tabular}

${ }^{a} \mathrm{E}^{\circ}$ values determined by cyclic voltammetry $(\mathrm{CV})$ at $20^{\circ} \mathrm{C}$ in $\mathrm{DCM}$ at $100 \mathrm{mVs}^{-1}, 0.1 \mathrm{M} \mathrm{Bu}_{4} \mathrm{NPF}_{6} ; \mathrm{E}^{\circ}=\left(\mathrm{E}_{\mathrm{pa}}+\right.$ $\left.\mathrm{E}_{\mathrm{pc}}\right) / 2$ and $\Delta \mathrm{E}=\left|\mathrm{E}_{\mathrm{pa}}-\mathrm{E}_{\mathrm{pc}}\right|$, referenced to $\left[\mathrm{Fc}^{*}\right]^{(+/ 0)} \cdot{ }^{\mathrm{b}} \mathrm{E}^{\circ}$ determined from differential pulse voltammetry (DPV), as $\mathrm{E}_{\mathrm{pa}}$ for the process in $\mathrm{CV}$ was at the limit of the solvent window.

\subsection{Photo-Reactivity of $L 1 R u-L 4 R u$}

UV irradiation (254 $\mathrm{nm}$ ) of [D3]acetonitrile solutions (2 mM) of each of L1Ru-L4Ru resulted in a photochemical reaction in all cases. At least one new set of signals appeared in the ${ }^{1} \mathrm{H}$ NMR of UV-irradiated samples, which increased in signal height relative to the initial spectrum over time (see Supplementary Material, Figures S41-S44). In all four cases, the major species being produced was confirmed to be $\left[\mathrm{Ru}(\text { bipy })_{2}\left(\mathrm{CD}_{3} \mathrm{CN}\right)_{2}\right]^{2+}$ through direct comparison with the ${ }^{1} \mathrm{H}$ NMR $\left(C D_{3} C N\right)$ of an independently synthesised sample of $\left[\mathrm{Ru}(\text { bipy })_{2}\left(\mathrm{CH}_{3} \mathrm{CN}\right)\right]\left(\mathrm{BF}_{4}\right)_{2}$. This was also confirmed using ESI-MS. Interestingly no signals corresponding to the liberated free ligands were observed in any case. Irradiation of $\mathbf{L 1 R u}-\mathbf{L} \mathbf{4} \mathbf{R u}$ under identical conditions in [D6]acetone resulted in no photo-reaction, suggesting a more coordinating solvent (or other ligand) was required for photo-ejection of L1-4 to proceed.

Complexes $\mathbf{L} \mathbf{R u}$ and $\mathbf{L} \mathbf{R} \mathbf{R}$ showed full dissociation of the $\left[\mathrm{Ru}(\mathrm{bipy})_{2}\left(\mathrm{CD}_{3} \mathrm{CN}\right)_{2}\right]^{2+}$ units. No signals of significant intensity were observed in either case which might indicate the formation of intermediate species (for instance, in the case of $\mathbf{L} 4 \mathbf{R u}$, where one $\left[\mathrm{Ru}(\text { bipy })_{2}\left(\mathrm{CD}_{3} \mathrm{CN}\right)_{2}\right]^{2+}$ unit had dissociated but the other had not yet). Interestingly, L2Ru and L4Ru underwent ligand ejection at different rates. Greater than 95\% of L2Ru ([D3]acetonitrile solution) was converted to $\left[\mathrm{Ru}(\text { bipy })_{2}\left(\mathrm{CD}_{3} \mathrm{CN}\right)_{2}\right]^{2+}$ after 7 days of irradiation, while $\mathbf{L} 4 \mathbf{R u}$ took less than 3 days under identical conditions (Figure 7). The explanation as to why $\mathbf{L} \mathbf{4 R \mathbf { u }}$ reaches a fully ejected state in less than half the time taken for the same process in L2Ru is not entirely clear, but we suggest two plausible reasons: L4Ru was able to absorb more photons in the appropriate energy range of the light source used, per $\mathrm{Ru}(\mathrm{II})$ centre, or perhaps once one $\mathrm{Ru}(\mathrm{II})$ centre is lost from $\mathbf{L} 4 \mathbf{R u}$, the free pytri binding pocket may have become involved in the second ejection process.

The behaviour of the reg-pytri analogues was significantly different to that of the inv-analogues. After 26 days of irradiation in [D3] acetonitrile solution, L1Ru had undergone approximately $75 \%$ conversion to the photoreaction products (based on the integration of key ${ }^{1} \mathrm{H}$ NMR signals). Signals that did not correspond to the starting Ru complex, nor $\left[\mathrm{Ru}(\mathrm{bipy})_{2}\left(\mathrm{CD}_{3} \mathrm{CN}\right)_{2}\right]^{2+}$ or the free ligand began to grow at the beginning of the irradiation experiment. These signals were presumed to be intermediate ligand ejection products (Scheme 1 below), where either the 1,2,3-triazole (intermediate a) or the pyridine (intermediate $b$ ) of the ferrocene ligand had been replaced by an acetonitrile solvent molecule, but not the other. This is consistent with the observation of at least two sets of these 
unassigned signals having similar chemical shifts and multiplicity appearing and is also consistent with previously reported photo ejection experiments of pytri ligands [49].

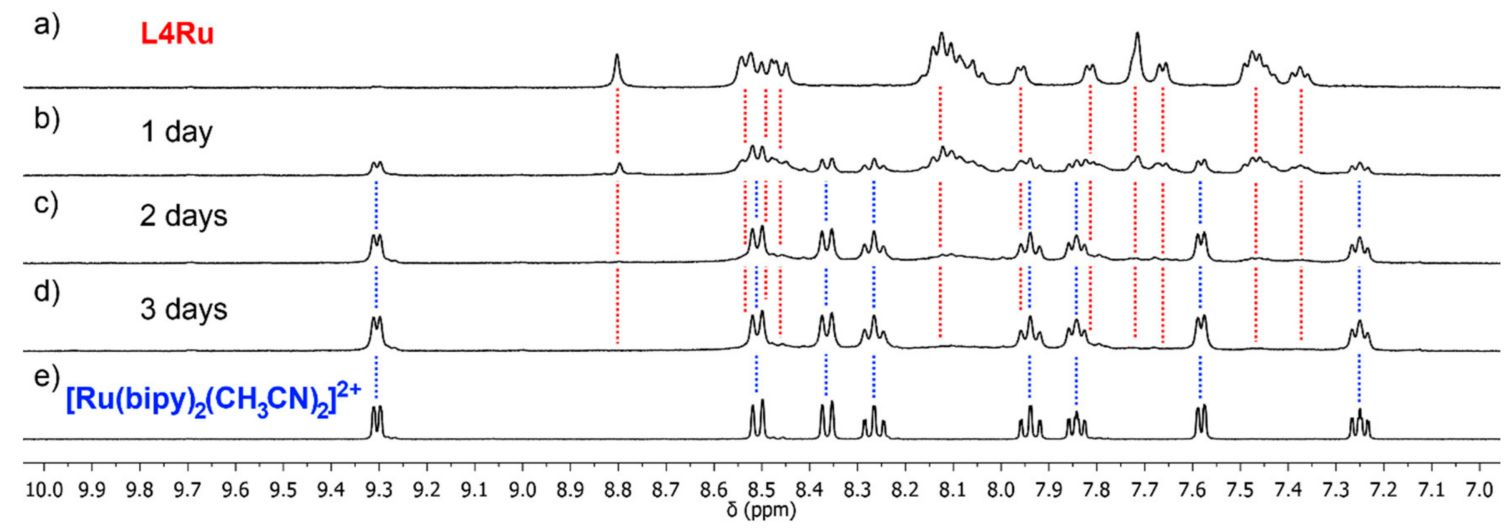

Figure 7. Partial stacked ${ }^{1} \mathrm{H}$ NMR spectra ( $400 \mathrm{MHz}, \mathrm{CD}_{3} \mathrm{CN}, 298 \mathrm{~K}$ ), showing the photo-ejection of $\left[\mathrm{Ru}(\text { bipy })_{2}\left(\mathrm{CD}_{3} \mathrm{CN}\right)_{2}\right]^{2+}$ (blue dashed lines) from L4Ru (red dashed lines) over time under UV (254 nm) irradiation; (a) ${ }^{1} \mathrm{H}$ NMR of unirradiated L4Ru, (b-d) ${ }^{1} \mathrm{H}$ NMR of L4Ru after 1-3 days of UV irradiation, and $(\mathbf{e}){ }^{1} \mathrm{H}$ NMR of independently synthesised $\left[\mathrm{Ru}(\text { bipy })_{2}\left(\mathrm{CH}_{3} \mathrm{CN}\right)_{2}\right]\left(\mathrm{BF}_{4}\right)_{2}$. Note: $\mathbf{L} 4$ is insoluble in acetonitrile, hence, no spectrum of a free ligand for comparison.

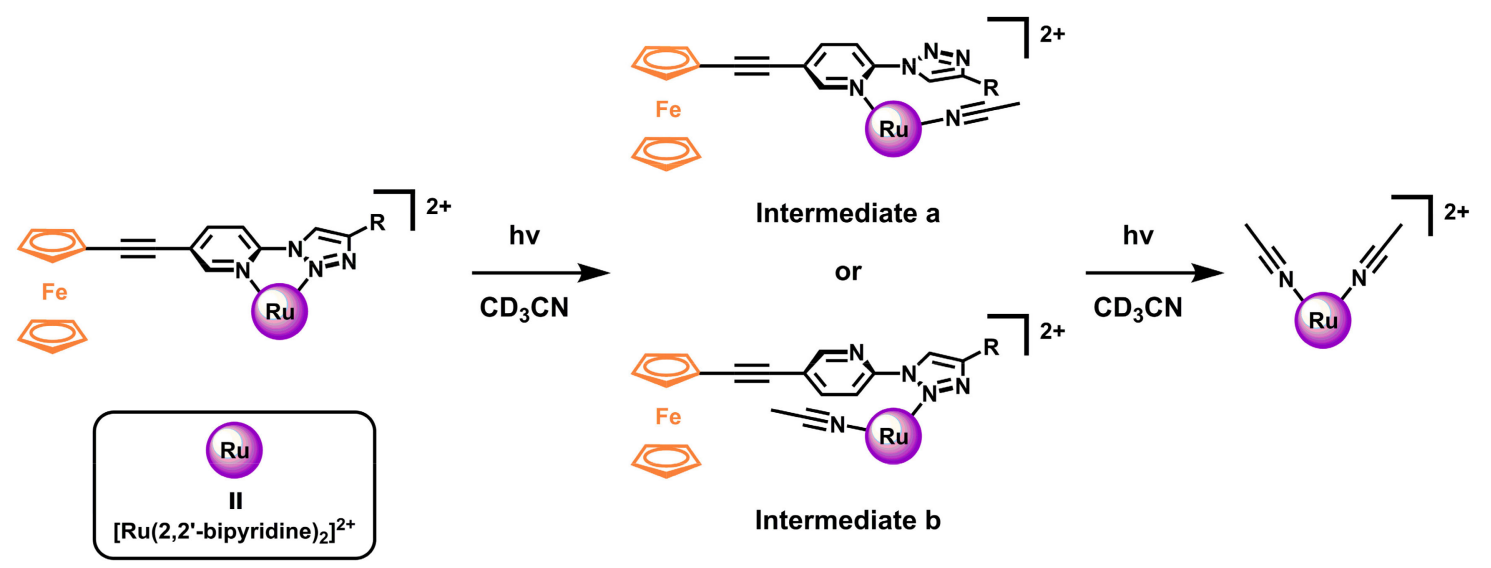

Scheme 1. Representative example of the formation of intermediate species, where one of either the pyridine or triazole of the 2-pyridyl-1,2,3-triazole is photo-ejected initially giving rise to either intermediate $\mathrm{a}$ or $\mathrm{b}$ before full ligand dissociation is achieved at a later time.

Interestingly, after the same length of time (26 days), L3Ru had reached a point where essentially none of the original signals of the intact L3Ru species were present. However, full conversion to $\left.[\mathrm{Ru} \text { (bipy) })_{2}\left(\mathrm{CD}_{3} \mathrm{CN}\right)_{2}\right]^{2+}$ had also not occurred, as a significant amount of the material appeared to be in an intermediate stage. When analogous $\left[\mathrm{Ru}(\text { bipy })_{2} \text { (reg-Bnpytri) }\right]^{2+}$ complexes (where reg-Bnpytri = 2-(1-benyzl-1H-1,2,3-triazol-4-yl)pyridine), which were not substituted with Fc, were irradiated (254 nm, [D3]acetonitrile), no photo-reaction was observed [49]. We propose a different absorption profile due to the substituents of the pytri ligands presented here as the likely cause of this difference.

With the photochemical behaviour of the four ruthenium complexes under UV irradiation determined, we turned our attention to the reverse process of thermal re-coordination. Our hypothesis was heating the [D3] acetonitrile solution of photo-reaction products would affect re-coordination of the Fc ligands and re-extended the rotors, thus rendering the system(s) reversible. However, heating the [D3]acetonitrile solutions of fully photo-ejected samples of $\mathbf{L} 2 \mathbf{R} \mathbf{u}$ and $\mathbf{L} 4 \mathbf{R} \mathbf{u}$ at $80^{\circ} \mathbf{C}$ in the dark, resulted in almost no change to the ${ }^{1} \mathrm{H}$ NMR of the mixtures within 7 days, and certainly no return of 
the signals corresponding to the original complexes. Samples of L1Ru and L3Ru in [D3]acetonitrile which had been irradiated for 26 days were also heated to $80^{\circ} \mathrm{C}$ in the dark. After $48 \mathrm{~h}$ no change to the ${ }^{1} \mathrm{H}$ NMR was observed. We then took completely photo-ejected samples of $\mathbf{L} \mathbf{2} \mathbf{R} \mathbf{u}$ and $\mathbf{L} \mathbf{4 R \mathbf { u }}$ that had not been heated and evaporated the [D3] acetonitrile solvent under reduced pressure to dryness. Re-dissolving the photo-reaction product residue in [D6]acetone and heating at $65{ }^{\circ} \mathrm{C}$ in the dark produced no reaction also.

The lack of re-coordination and the absence of free ligand signals in the NMR spectra of the photo-irradiated samples suggested that the Fc ligands may be decomposing under the conditions of the experiments. To test this postulate control experiments were carried out on fresh separate samples of $\mathbf{L} 1$ and L2. Samples of L1 and L2 in [D3] acetonitrile were irradiated under the same conditions as the complexes and were monitored by ${ }^{1} \mathrm{H}$ NMR (see Supplementary Material Figures S49-S50). Within one day the orange colour of the solution had lessened, and brown precipitate was being generated, confirming the UV-promoted degradation of the ligands.

Additionally, we attempted to react each of the model ligands L1 and L2 with one equivalent of independently synthesised $\left[\mathrm{Ru}(\text { bipy })_{2}\left(\mathrm{CH}_{3} \mathrm{CN}\right)_{2}\right]\left(\mathrm{BF}_{4}\right)_{2}$ to generate $\mathbf{L 1 R \mathbf { u }}$ and $\mathbf{L} \mathbf{2} \mathbf{R} \mathbf{u}$ from the two components that should be present in the photo-reaction product mixtures. Combining $\left[\mathrm{Ru}(\text { bipy })_{2}\left(\mathrm{CH}_{3} \mathrm{CN}\right)_{2}\right]\left(\mathrm{BF}_{4}\right)_{2}$ and either $\mathbf{L 1}$ or $\mathbf{L} 2$ in [D3] acetonitrile and heating at $80{ }^{\circ} \mathrm{C}$ in the dark for $24 \mathrm{~h}$ resulted in the replacement of the $\mathrm{CH}_{3} \mathrm{CN}$ ligands with [D3] acetonitrile, as evidenced by ${ }^{1} \mathrm{H}$ NMR. However, none of $\mathbf{L 1 R u}$ or L2Ru was generated (see Supplementary Material, Figures S45 and S46). The sample of these two mixtures after $24 \mathrm{~h}$ of heating had also produced some black precipitate; presumably degraded Fc ligand, generated due to prolonged heating in the coordinating [D3] acetonitrile solvent. This was corroborated by the decrease in intensity of the signals of the free ligands relative to the $\left[\mathrm{Ru}(\text { bipy })_{2}\left(\mathrm{CH}_{3} \mathrm{CN}\right)_{2}\right]\left(\mathrm{BF}_{4}\right)_{2}$ signals in the ${ }^{1} \mathrm{H} \mathrm{NMR}$. Separate, pure, samples of $\mathbf{L 1}$ and $\mathbf{L} 2$ were heated to $80^{\circ} \mathrm{C}$ in [D3] acetonitrile, and within $24 \mathrm{~h}$ a significant amount of brown precipitate had formed confirming the Fc ligands degrade when heated in acetonitrile solution. The thermal coordination experiments between each model ligand and $\left.[\mathrm{Ru} \text { (bipy) })_{2}\left(\mathrm{CH}_{3} \mathrm{CN}\right)_{2}\right]\left(\mathrm{BF}_{4}\right)_{2}$ were then repeated in [D6]acetone solution (see Supplementary Material, Figures S47 and S48). Interestingly, [D6]acetone molecules had begun replacing the coordinated acetonitrile of $\left[\mathrm{Ru}(\text { bipy })_{2}\left(\mathrm{CH}_{3} \mathrm{CN}\right)_{2}\right]\left(\mathrm{BF}_{4}\right)_{2}$ at room temperature, in the time required to collect a ${ }^{1} \mathrm{H}$ NMR. Upon heating at $65{ }^{\circ} \mathrm{C}$ in the dark for $4 \mathrm{~h}$, signals which corresponded to those of L1Ru and $\mathbf{L} \mathbf{2} \mathbf{u}$ had appeared in the respective mixtures. The proportion of $\mathbf{L 1 R} \mathbf{u}$ and $\mathbf{L} \mathbf{2} \mathbf{R} \mathbf{u}$ grew overtime with continued heating. After 12 days the ${ }^{1} \mathrm{H}$ NMR of the mixture of $\mathbf{L} \mathbf{1}$ and $\left[\mathrm{Ru}(\text { bipy })_{2}\left(\mathrm{CH}_{3} \mathrm{CN}\right)_{2}\right]\left(\mathrm{BF}_{4}\right)_{2}$ was almost identical to that of L1Ru. The equivalent process was observed for L2, however at a lower rate. This showed that the thermal re-coordination of at least $\mathbf{L} \mathbf{1}$ or $\mathbf{L} 2$ to $\left[\mathrm{Ru}(\text { bipy })_{2}\left(\mathrm{CH}_{3} \mathrm{CN}\right)_{2}\right]^{2+}$ was, in fact, possible, but not from the mixture produced by UV-irradiation in [D3] acetonitrile, due to the decomposition of the ligands post $\mathrm{Ru}(\mathrm{II})$ photo-ejection.

The equivalent re-coordination experiments in [D6]acetone for L3 and L4 were not attempted, as the ejection from L3 was extremely slow, and both have a very low solubility in acetone, making neither an ideal candidate for reversibly switchable rotors.

\section{Conclusions}

In summary, 2-pyridyl-1,2,3-triazole (pytri) ferrocene rotor ligands and the corresponding $\left[\mathrm{Ru}(\text { bipy })_{2}\right]^{2+}$ complexes were successfully synthesised and characterised. The ferrocene rotors adopt a syn $\pi$-stacked conformation. Complexation of the rotors to two $\left[\operatorname{Ru}(\text { bipy })_{2}\right]^{2+} u_{\text {nits }}$ generates a conformational switch to an anti-extended state. UV irradiation experiments resulted in photo-labilisation of the $\mathrm{Ru}(\mathrm{II})$ units, and formation of $\left[\mathrm{Ru}(\text { bipy })_{2}\left(\mathrm{CH}_{3} \mathrm{CN}\right)_{2}\right]^{2+}$, concomitant with contraction of the ferrocene rotors to the syn $\pi$-stacked conformation. Both the 'regular' (L3Ru) and 'inverse' pytri rotor complexes (L4Ru) underwent photo-ejection in acetonitrile solution. However, as expected from earlier model studies the inv-system photo-ejected more rapidly (3-7 days) than the reg-complexes (approx. a month). While photo-ejection of the $\left[\mathrm{Ru}(\mathrm{bipy})_{2}\left(\mathrm{CH}_{3} \mathrm{CN}\right)_{2}\right]^{2+}$ units completed 
an extension-and-contraction cycle, further reversible switching could not be achieved as the Fc ligands decomposed under the conditions of the UV-irradiation experiments.

While the current Fc switches are unstable under the photo-switching conditions, the results obtained herein suggest that ruthenium(II) based ligand photo-election reactions could be exploited to develop reversible photo-switches in correctly designed, more robust systems. Efforts towards new more rapid and robust ruthenium(II) based photo-switches based on other "click" 1,2,3-triazoles ligands are underway.

\section{Materials and Methods}

Unless otherwise stated, all reagents were purchased from commercial sources and used without further purification. 1,1'-diiodoferrocene was synthesised and purified according to a literature preparation [70]. The ligands L1 and L3 were synthesised using our previously reported methods [67]. Solvents were laboratory reagent grade. Substances (and their abbreviations) used herein include, methanol $(\mathrm{MeOH})$, dichloromethane (DCM), tetrahydrofuran (THF), acetonitrile $\left(\mathrm{CH}_{3} \mathrm{CN}\right)$, ethylenediaminetetraacetate (EDTA), tris((1-benzyl-1H-1,2,3-triazol-4-yl)methyl)amine (TBTA). Petrol refers to the fraction of petroleum ether boiling in the range $40-60{ }^{\circ} \mathrm{C} .{ }^{1} \mathrm{H}$ and ${ }^{13} \mathrm{C} \mathrm{NMR}$ spectra were recorded on either a $400 \mathrm{MHz}$ Varian $400 \mathrm{MR}$ or Varian $500 \mathrm{MHz}$ VNMRS spectrometer (Varian, Santa Clara, CA, USA). Chemical shifts are reported in parts per million and referenced to residual solvent peaks $\left(\mathrm{CDCl}_{3}:{ }^{1} \mathrm{H} \delta 7.26 \mathrm{ppm},{ }^{13} \mathrm{C} \delta 77.16 \mathrm{ppm} ; \mathrm{CD}_{3} \mathrm{CN}:{ }^{1} \mathrm{H} \delta 1.94,{ }^{13} \mathrm{C} \delta 1.32\right.$, $118.26 \mathrm{ppm}, d_{6}$-acetone: $\left.{ }^{1} \mathrm{H} \delta 2.05 \mathrm{ppm} ;{ }^{13} \mathrm{C} \delta 29.84,206.26 \mathrm{ppm}\right)$. Coupling constants $(J)$ are reported in Hertz (Hz). Standard abbreviations indicating multiplicity were used as follows: $\mathrm{m}=$ multiplet, $\mathrm{q}=$ quartet $\mathrm{t}=$ triplet, $\mathrm{dt}=$ double triplet, $\mathrm{d}=$ doublet, $\mathrm{dd}=$ double doublet, $\mathrm{ddd}=$ double double doublet, $\mathrm{s}=$ singlet. Infrared spectra were recorded on a Bruker ALPHA FT-IR spectrometer with an attached ALPHA-P Attenuated Total-internal Reflection (ATR) measurement module (Bruker Daltonik, Bremen, Germany). Microanalyses were performed at the Campbell Microanalytical Laboratory at the University of Otago. Electrospray ionisation mass spectra (ESI-MS) were collected on a Bruker micro-TOF-Q spectrometer (Bruker Daltonic, Bremen, Germany). UV-visible absorption spectra were acquired with a Shimadzu UV-2600 UV-Vis spectrophotometer (Shimadzu, Kyoto, Japan). A CEM S-class microwave reactor (CEM corporation, Mathews, NC, USA) was used to carry out microwave enhanced reactions.

Safety Note: Whilst no problems were encountered during the course of this work, azide compounds are potentially explosive, and appropriate precautions should be taken when working with them.

Synthesis of L2: To degassed toluene $(5 \mathrm{~mL})$ was added 2-(6-azido-3-pyridinyl)ethynylferrocene (220 mg, $4.95 \mathrm{mmol}),\left[\mathrm{Cu}\left(\mathrm{CH}_{3} \mathrm{CN}\right)_{4}\right]\left(\mathrm{PF}_{6}\right)(0.369 \mathrm{mg}, 0.989 \mathrm{mmol})$, TBTA $(0.262 \mathrm{mg}, 0.495 \mathrm{mmol})$, and 1-octyne $(1.46 \mathrm{~mL}, 9.89 \mathrm{mmol})$ and the mixture was refluxed under an inert atmosphere for $48 \mathrm{~h}$. The cooled reaction mixture was diluted with DCM $(100 \mathrm{~mL})$ and EDTA $/ \mathrm{NH}_{4} \mathrm{OH}_{(\mathrm{aq})}$ solution $(0.1 \mathrm{M}$, $100 \mathrm{~mL}$ ) and stirred vigorously for $4 \mathrm{~h}$. The organic layer was separated and aqueous phase was extracted with DCM $(2 \times 50 \mathrm{~mL})$. The combined organic layers were washed with brine $(100 \mathrm{~mL})$, dried over $\mathrm{Na}_{2} \mathrm{SO}_{4}$, filtered, and the solvents were removed under reduced pressure. The residue was purified by column chromatography (silica gel, 9:1 DCM/acetone) giving the product as an orange solid upon removal of solvents. Yield $268 \mathrm{mg}, 91 \%$. M. P. $=82{ }^{\circ} \mathrm{C} ;{ }^{1} \mathrm{H}$ NMR $\left(400 \mathrm{MHz}, \mathrm{CDCl}_{3}\right) \delta$ $8.55\left(\mathrm{~d}, J=2.0 \mathrm{~Hz}, 1 \mathrm{H}, \mathrm{H}_{\mathrm{d}}\right), 8.30\left(\mathrm{~s}, 1 \mathrm{H}, \mathrm{H}_{\mathrm{g}}\right), 8.14\left(\mathrm{~d}, J=8.4 \mathrm{~Hz}, 1 \mathrm{H}, \mathrm{H}_{\mathrm{f}}\right), 7.94(\mathrm{dd}, J=8.5,2.1 \mathrm{~Hz}$, $\left.1 \mathrm{H}, \mathrm{H}_{\mathrm{e}}\right), 4.55\left(\mathrm{t}, J=1.7 \mathrm{~Hz}, 2 \mathrm{H}, \mathrm{H}_{\mathrm{c}}\right), 4.31\left(\mathrm{t}, J=1.8 \mathrm{~Hz}, 2 \mathrm{H}, \mathrm{H}_{\mathrm{b}}\right), 4.27\left(\mathrm{~s}, 5 \mathrm{H}, \mathrm{H}_{\mathrm{a}}\right), 2.81(\mathrm{t}, J=7.7 \mathrm{~Hz}$, $\left.2 \mathrm{H}, \mathrm{H}_{\mathrm{h}}\right), 1.74\left(\mathrm{p}, J=7.6 \mathrm{~Hz}, 2 \mathrm{H}, \mathrm{H}_{\mathrm{i}}\right), 1.40\left(\mathrm{~m}, 2 \mathrm{H}, \mathrm{H}_{\mathrm{j}}\right), 1.33\left(\mathrm{q}, J=3.4 \mathrm{~Hz}, 4 \mathrm{H}, \mathrm{H}_{\mathrm{k}}\right.$ and $\left.\mathrm{H}_{\mathrm{l}}\right), 0.89(\mathrm{t}$, $\left.J=7.0 \mathrm{~Hz}, 3 \mathrm{H}, \mathrm{H}_{\mathrm{m}}\right) ;{ }^{13} \mathrm{C} \mathrm{NMR}\left(101 \mathrm{MHz}, \mathrm{CDCl}_{3}\right) \delta{ }^{13} \mathrm{C} \mathrm{NMR}\left(101 \mathrm{MHz}, \mathrm{CDCl}_{3}\right) \delta 150.7,149.2,147.5$, $141.2,120.9,118.2,113.2,93.5,81.8,71.8,70.2,69.5,64.1,31.7,29.4,29.0,25.8,22.7,14.2$; IR (ATR): $v\left(\mathrm{~cm}^{-1}\right) 3139,2951,2922,2854,2212,1591,1493,1456,1432,1230,1031,815$; HR-ESI MS: (MeOH) $m / z=439.1571$ (calc. for $\mathrm{C}_{25} \mathrm{H}_{27} \mathrm{~N}_{4} \mathrm{Fe} 439.1580$ ), 461.1373 (calc. for $\mathrm{C}_{25} \mathrm{H}_{26} \mathrm{~N}_{4} \mathrm{Fe} \cdot \mathrm{Na}$ 461.1399); UV-Vis 
$\left(\mathrm{CH}_{2} \mathrm{Cl}_{2}\right) \lambda_{\max }\left(\varepsilon / 10^{3} \mathrm{~L} \mathrm{~mol}^{-1} \mathrm{~cm}^{-1}\right) 307$ (23), 444 (1); Anal. calc. for $\mathrm{C}_{25} \mathrm{H}_{26} \mathrm{~N}_{4} \mathrm{Fe} \mathrm{C}, 68.50 ; \mathrm{H}, 5.98 ; \mathrm{N}$, $12.78 \%$. Found C, 68.46; H, 6.18; N, 12.87\%.

Synthesis of L4: 1,1'-Diiodoferrocene (469 mg, $1.07 \mathrm{mmol}$ ), 5-ethynyl-2-(4-hexyl-1H-1,2,3-triazol1-yl)pyridine (600 mg, $2.36 \mathrm{mmol}), \mathrm{CuI}(40.8 \mathrm{mg}, 0.214 \mathrm{mmol}),\left[\mathrm{Pd}\left(\mathrm{CH}_{3} \mathrm{CN}\right)_{2}(\mathrm{Cl})_{2}\right](16.7 \mathrm{mg}$, $0.064 \mathrm{mmol})$, and $\left[\mathrm{PH}\left({ }^{\mathrm{t}} \mathrm{Bu}\right)_{3}\right]\left(\mathrm{BF}_{4}\right)(37.3 \mathrm{mg}, 0.129 \mathrm{mmol})$ were combined in degassed diisopropylamine $(15 \mathrm{~mL})$ and stirred under microwave irradiation $(200 \mathrm{~W})$ at $100{ }^{\circ} \mathrm{C}$ for $2 \mathrm{~h}$. The crude reaction mixture was diluted with DCM $(50 \mathrm{~mL})$ and washed with EDTA $/ \mathrm{NH}_{4} \mathrm{OH}_{(\mathrm{aq})}(0.1 \mathrm{M}, 100 \mathrm{~mL})$. The organic layer was separated and the aqueous phase extracted with DCM $(4 \times 50 \mathrm{~mL})$. The combined organic layers were washed with brine $(80 \mathrm{~mL})$, dried over $\mathrm{Na}_{2} \mathrm{SO}_{4}$, filtered, and the solvent was removed under reduced pressure. The residue was purified by column chromatography (silica gel, gradient DCM, then 9:1 DCM/acetone) to give an orange solid upon removal of solvent. The product was further purified by precipitation from DCM with petrol, collection by filtration, and desiccating. Yield: $509 \mathrm{mg}, 68 \%$. M. P. $=144^{\circ} \mathrm{C} ;{ }^{1} \mathrm{H}$ NMR $\left(400 \mathrm{MHz}, \mathrm{CDCl}_{3}\right) \delta 8.35\left(\mathrm{dd}, J=2.1,0.8 \mathrm{~Hz}, 1 \mathrm{H}, \mathrm{H}_{\mathrm{c}}\right), 8.10(\mathrm{~d}$, $\left.J=0.8 \mathrm{~Hz}, 1 \mathrm{H}, \mathrm{H}_{\mathrm{f}}\right), 8.04\left(\mathrm{dd}, J=8.5,0.8 \mathrm{~Hz}, 1 \mathrm{H}, \mathrm{H}_{\mathrm{e}}\right), 7.84\left(\mathrm{dd}, J=8.5,2.2 \mathrm{~Hz}, 1 \mathrm{H}, \mathrm{H}_{\mathrm{d}}\right), 4.61(\mathrm{t}, J=1.9 \mathrm{~Hz}$, $\left.2 \mathrm{H}, \mathrm{H}_{\mathrm{b}}\right), 4.40\left(\mathrm{t}, J=1.9 \mathrm{~Hz}, 2 \mathrm{H}, \mathrm{H}_{\mathrm{a}}\right), 2.76\left(\mathrm{t}, J=7.7 \mathrm{~Hz}, 2 \mathrm{H}, \mathrm{H}_{\mathrm{g}}\right), 1.72\left(\mathrm{p}, J=7.3 \mathrm{~Hz}, 2 \mathrm{H}, \mathrm{H}_{\mathrm{h}}\right), 1.45-1.37(\mathrm{~m}$, $\left.2 \mathrm{H}, \mathrm{H}_{\mathrm{i}}\right), 1.36-1.30\left(\mathrm{~m}, 4 \mathrm{H}, \mathrm{H}_{\mathrm{j}}\right.$ and $\left.\mathrm{H}_{\mathrm{k}}\right), 0.89\left(\mathrm{t}, J=7.0 \mathrm{~Hz}, 2 \mathrm{H}, \mathrm{H}_{\mathrm{l}}\right) ;{ }^{13} \mathrm{C} \mathrm{NMR}\left(101 \mathrm{MHz}, \mathrm{CDCl}_{3}\right) \delta 150.6$, 149.2, 147.4, 141.0, 120.5, 118.0, 113.1, 91.7, 83.1, 73.2, 71.2, 66.7, 31.8, 29.3, 29.1, 25.8, 22.7, 14.2; IR (ATR): $v\left(\mathrm{~cm}^{-1}\right) 3123,3104,2924,2855,2212,1592,1500,1464,1434,1238,1047,823$; HR-ESI MS: (MeOH) $m / z=713.2728$ (calc. for $\mathrm{C}_{40} \mathrm{H}_{42} \mathrm{~N}_{8} \mathrm{Fe} \cdot \mathrm{Na} 713.2775$ ), 1403.5553 (calc. for $\mathrm{C}_{80} \mathrm{H}_{84} \mathrm{~N}_{16} \mathrm{Fe} \cdot \mathrm{Na}$ 1403.5661); UV-Vis $\left(\mathrm{CH}_{2} \mathrm{Cl}_{2}\right) \lambda_{\max }\left(\varepsilon / 10^{3} \mathrm{~L} \mathrm{~mol}^{-1} \mathrm{~cm}^{-1}\right) 304$ (45), 409 (1); Anal. calc. for $\mathrm{C}_{40} \mathrm{H}_{42} \mathrm{~N}_{8} \mathrm{Fe} \cdot 0.3 \mathrm{H}_{2} \mathrm{O}$ C, 69.02; H, 6.17; N, 16.10\%. Found C, 68.77; H, 6.21; N, 16.33\%.

General procedure for synthesis of $\left[\mathrm{Ru}(\mathrm{bipy})_{2}\right]^{2+}$ complexes of L1-L4: $\left[\mathrm{Ru}(\mathrm{bipy})_{2}(\mathrm{Cl})_{2}\right](1.2 \mathrm{eq}$. for $\mathbf{L} 1$ and $\mathbf{L} 2$, and 2.2 eq. for $\mathbf{L} 3$ and $\mathbf{L 4}$ ) and $\mathrm{AgBF}_{4}$ (2.0 eq./ $\mathrm{Ru}$ ion) were combined in degassed acetone (typically $5 \mathrm{~mL}$ ) in the dark, and stirred at room temperature for two hours. The resulting $\mathrm{AgCl}$ precipitate was filtered off through celite, and the solution was added to a degassed acetone solution (typically $10 \mathrm{~mL}$ ) of the desired ferrocene ligand under argon. The mixture was then refluxed in the dark overnight. The resulting solution was filtered through Celite and the solvent removed under reduced pressure. The residue was taken up in the minimum amount of DCM, precipitated by addition of diethyl ether, filtered over a vacuum and rinsed with diethyl ether $(2 \times 5 \mathrm{~mL})$. The air-dried products were then further dried in a desiccator for at least $24 \mathrm{~h}$.

Synthesis of $\left[\mathbf{L 1 R u}(\text { bipy })_{2}\right]\left(\mathbf{B F}_{4}\right)_{2}$ : Following the general procedure with: $39.8 \mathrm{mg}(0.082 \mathrm{mmol})$ of $\left[\mathrm{Ru}(\text { bipy })_{2}(\mathrm{Cl})_{2}\right], 32.0 \mathrm{mg}(0.164 \mathrm{mmol})$ of $\mathrm{AgBF}_{4}$, and $30.0 \mathrm{mg}(0.068 \mathrm{mmol})$ of $\mathbf{L}$. The product was obtained as an orange powder. Yield: $65 \mathrm{mg}\left(93 \%\right.$, based on L1). ${ }^{1} \mathrm{H}$ NMR (400 MHz, $d_{6}$-acetone) $\delta$ $9.26\left(\mathrm{~s}, 1 \mathrm{H}, \mathrm{H}_{\mathrm{g}}\right), 8.88-8.82\left(\mathrm{~m}, 2 \mathrm{H}, \mathrm{H}_{\text {bipy }}\right), 8.81\left(\mathrm{dt}, J=8.2,1.1 \mathrm{~Hz}, 1 \mathrm{H}, \mathrm{H}_{\text {bipy }}\right), 8.77(\mathrm{dt}, J=8.0,1.0 \mathrm{~Hz}$, $\left.1 \mathrm{H}, \mathrm{H}_{\text {bipy }}\right), 8.37\left(\mathrm{~d}, J=8.3 \mathrm{~Hz}, 1 \mathrm{H}, \mathrm{H}_{\mathrm{f}}\right), 8.31\left(\mathrm{~d}, J=5.6 \mathrm{~Hz}, 1 \mathrm{H}, \mathrm{H}_{\text {bipy }}\right), 8.27-8.11\left(\mathrm{~m}, 7 \mathrm{H}, \mathrm{H}_{\mathrm{e}}\right.$ and $\left.\mathrm{H}_{\text {bipy }}\right)$, 8.00 (ddd, $\left.J=5.7,1.6,0.8 \mathrm{~Hz}, 1 \mathrm{H}, \mathrm{H}_{\text {bipy }}\right), 7.84\left(\mathrm{~s}, 1 \mathrm{H}, \mathrm{H}_{\mathrm{d}}\right), 7.66-7.58\left(\mathrm{~m}, 3 \mathrm{H}, \mathrm{H}_{\text {bipy }}\right), 7.53$ (ddd, $J=7.6$, $\left.5.7,1.3 \mathrm{~Hz}, 1 \mathrm{H}, \mathrm{H}_{\text {bipy }}\right), 4.51\left(\mathrm{t}, J=7.0 \mathrm{~Hz}, 2 \mathrm{H}, \mathrm{H}_{\mathrm{h}}\right), 4.47\left(\mathrm{~s}, 2 \mathrm{H}, \mathrm{H}_{\mathrm{c}}\right), 4.36\left(\mathrm{~s}, 2 \mathrm{H}, \mathrm{H}_{\mathrm{b}}\right), 4.21\left(\mathrm{~s}, 5 \mathrm{H}, \mathrm{H}_{\mathrm{a}}\right)$, $1.87\left(\mathrm{p}, J=7.1 \mathrm{~Hz}, 2 \mathrm{H}, \mathrm{H}_{\mathrm{i}}\right), 1.24-1.11\left(\mathrm{~m}, 6 \mathrm{H}, \mathrm{H}_{\mathrm{j}}, \mathrm{H}_{\mathrm{k}}\right.$, and $\left.\mathrm{H}_{1}\right), 0.81\left(\mathrm{t}, J=6.9 \mathrm{~Hz}, 3 \mathrm{H}, \mathrm{H}_{\mathrm{m}}\right) ;{ }^{13} \mathrm{C}$ NMR $\left(101 \mathrm{MHz}, \mathrm{CDCl}_{3}\right) \delta 158.8,158.6,158.3,158.1,153.9,153.3,153.2,153.1,153.1,150.5,148.3,141.0,139.0$ ( 2 coincident signals), 139.0, 138.7, 128.8, 128.7, 128.6, 127.9, 127.4, 125.4, 125.4, 124.9, 124.6, 123.7, 123.3, 96.6, 81.3, 72.5, 72.5, 70.9, 70.6, 65.1, 53.0, 31.6, 30.2, 26.3, 23.0, 14.2; IR (ATR): $v\left(\mathrm{~cm}^{-1}\right)$ 3116, 2929, 2861, 2206, 1604, 1580, 1466, 1446, 1053, 1034, 765; HR-ESI MS: (MeOH) $m / z=426.0975$ (calc. for $\mathrm{C}_{45} \mathrm{H}_{42} \mathrm{FeN}_{8} \mathrm{Ru}^{2+}$ 426.0964), 939.1941 (calc. for $\mathrm{C}_{45} \mathrm{H}_{42} \mathrm{FeN}_{8} \mathrm{RuBF}_{4}{ }^{+}$939.1969); UV-Vis $\left(\mathrm{CH}_{2} \mathrm{Cl}_{2}\right) \lambda_{\max }$ $\left(\varepsilon / 10^{3} \mathrm{~L} \mathrm{~mol}^{-1} \mathrm{~cm}^{-1}\right) 288$ (75), 422 (10), 449 (10); Anal. calc. for $\mathrm{C}_{45} \mathrm{H}_{42} \mathrm{FeN}_{8} \mathrm{RuB}_{2} \mathrm{~F}_{8} \mathrm{C}, 49.07 ; \mathrm{H}, 3.84$; $\mathrm{N}, 10.17 \%$. Found C, $49.23 ; \mathrm{H}, 3.76 ; \mathrm{N}, 10.47 \%$.

Synthesis of [L2Ru(bipy $\left.)_{2}\right]\left(\mathbf{B F}_{4}\right)_{2}$ : Following the general procedure with: $39.8 \mathrm{mg}(0.082 \mathrm{mmol})$ of $\left[\mathrm{Ru}(\text { bipy })_{2}(\mathrm{Cl})_{2}\right], 32.0 \mathrm{mg}(0.164 \mathrm{mmol})$ of $\mathrm{AgBF}_{4}$, and $30.0 \mathrm{mg}(0.068 \mathrm{mmol})$ of $\mathbf{L 2}$. The product was obtained as a brown powder. Yield: $66 \mathrm{mg}\left(94 \%\right.$, based on L2). ${ }^{1} \mathrm{H}$ NMR (400 MHz, $d_{6}$-acetone) $\delta 9.34$ $\left(\mathrm{s}, 1 \mathrm{H}, \mathrm{H}_{\mathrm{g}}\right), 8.89-8.84\left(\mathrm{~m}, 2 \mathrm{H}, \mathrm{H}_{\text {bipy }}\right), 8.83\left(\mathrm{~d}, J=8.2 \mathrm{~Hz}, 1 \mathrm{H}, \mathrm{H}_{\text {bipy }}\right), 8.79\left(\mathrm{~d}, J=8.3 \mathrm{~Hz}, 1 \mathrm{H}, \mathrm{H}_{\text {bipy }}\right), 8.54$ $\left(\mathrm{d}, J=8.6 \mathrm{~Hz}, 1 \mathrm{H}, \mathrm{H}_{\mathrm{f}}\right.$ and $\left.\mathrm{H}_{\text {bipy }}\right), 8.42-8.36\left(\mathrm{~m}, 2 \mathrm{H}, \mathrm{H}_{\mathrm{e}}\right.$ and $\left.\mathrm{H}_{\text {bipy }}\right), 8.31-8.17\left(\mathrm{~m}, 5 \mathrm{H}, \mathrm{H}_{\text {bipy }}\right), 8.08-8.03$ 
$\left(\mathrm{m}, 2 \mathrm{H}, \mathrm{H}_{\mathrm{d}}\right.$ and $\left.\mathrm{H}_{\text {bipy }}\right), 7.99\left(\mathrm{dd}, J=5.5,1.2 \mathrm{~Hz}, 1 \mathrm{H}, \mathrm{H}_{\text {bipy }}\right), 7.64\left(\mathrm{~m}, 3 \mathrm{H}, \mathrm{H}_{\text {bipy }}\right), 7.59-7.53\left(\mathrm{~m}, 1 \mathrm{H}, \mathrm{H}_{\text {bipy }}\right)$, $4.46\left(\mathrm{~m}, 2 \mathrm{H}, \mathrm{H}_{\mathrm{c}}\right), 4.36\left(\mathrm{t}, J=1.9 \mathrm{~Hz}, 2 \mathrm{H}, \mathrm{H}_{\mathrm{b}}\right), 4.20\left(\mathrm{~s}, 5 \mathrm{H}, \mathrm{H}_{\mathrm{a}}\right), 2.75-2.70\left(\mathrm{~m}, 1 \mathrm{H}, \mathrm{H}_{\mathrm{h}}\right), 1.68-1.56(\mathrm{~m}, 2 \mathrm{H}$, $\left.\mathrm{H}_{\mathrm{i}}\right), 1.31-1.19\left(\mathrm{~m}, 6 \mathrm{H}, \mathrm{H}_{\mathrm{j}}, \mathrm{H}_{\mathrm{k}}\right.$, and $\left.\mathrm{H}_{\mathrm{l}}\right), 0.84\left(\mathrm{t}, J=6.5 \mathrm{~Hz}, 3 \mathrm{H}, \mathrm{H}_{\mathrm{m}}\right) ;{ }^{13} \mathrm{C} \mathrm{NMR}\left(101 \mathrm{MHz}, \mathrm{CDCl}_{3}\right) \delta 158.5$, $158.5,158.2,157.9,153.9,153.4,153.4,153.4,153.3,153.0,148.3,143.2,139.5,139.5$ (2 coincident signals), $139.2,129.0,128.8,128.7,128.2,125.6,125.5,125.1,124.8,124.5,124.0,115.6,97.2,80.7,72.5,72.5,70.9$, 70.7, 63.6, 32.1, 29.2, 29.1, 26.2, 23.2, 14.3; IR (ATR): $v\left(\mathrm{~cm}^{-1}\right)$ 3082, 2928, 2857, 2207, 1604, 1504, 1466, 1446, 1245, 1053, 1034, 764; HR-ESI MS: (MeOH) $m / z=426.0987$ (calc. for $\mathrm{C}_{45} \mathrm{H}_{42} \mathrm{FeN}_{8} \mathrm{Ru}^{2+} 426.0964$ ), 939.1963 (calc. for $\mathrm{C}_{45} \mathrm{H}_{42} \mathrm{FeN}_{8} \mathrm{RuBF}_{4}{ }^{+}$939.1969); UV-Vis $\left(\mathrm{CH}_{2} \mathrm{Cl}_{2}\right) \lambda_{\max }\left(\varepsilon / 10^{3} \mathrm{~L} \mathrm{~mol}^{-1} \mathrm{~cm}^{-1}\right) 285$ (68), 428 (13); Anal. calc. for $\mathrm{C}_{45} \mathrm{H}_{42} \mathrm{FeN}_{8} \mathrm{RuB}_{2} \mathrm{~F}_{8} \mathrm{C}, 49.07 ; \mathrm{H}, 3.84 ; \mathrm{N}, 10.17 \%$. Found C, 49.44; $\mathrm{H}, 4.03$; N, $10.47 \%$.

Synthesis of [ $\left[\mathbf{L} 3\left(\mathrm{Ru}\left(\mathrm{bipy}_{2}\right)_{2}\right]\left(\mathrm{BF}_{4}\right)_{4}\right.$ : Following the general procedure with: $61.7 \mathrm{mg}(0.127 \mathrm{mmol})$ of $\left[\mathrm{Ru}(\text { bipy })_{2}(\mathrm{Cl})_{2}\right], 49.6 \mathrm{mg}(0.255 \mathrm{mmol})$ of $\mathrm{AgBF}_{4}$, and $40.0 \mathrm{mg}(0.058 \mathrm{mmol})$ of L3. The product was obtained as an orange powder. Yield: $100 \mathrm{mg}\left(93 \%\right.$, based on L3). ${ }^{1} \mathrm{H} \mathrm{NMR}\left(400 \mathrm{MHz}, d_{6}\right.$-acetone) $\delta$ $9.22\left(\mathrm{~s}, 2 \mathrm{H}, \mathrm{H}_{\mathrm{f}}\right), 8.89\left(\mathrm{dd}, J=8.5,3.6 \mathrm{~Hz}, 2 \mathrm{H}, \mathrm{H}_{\text {bipy }}\right), 8.84-8.73\left(\mathrm{~m}, 6 \mathrm{H}, \mathrm{H}_{\text {bipy }}\right), 8.31-8.07\left(\mathrm{~m}, 15 \mathrm{H}, \mathrm{H}_{\mathrm{e}^{\prime}}\right.$ and $\left.\mathrm{H}_{\text {bipy }}\right), 8.04\left(\mathrm{~d}, J=8.3 \mathrm{~Hz}, 1 \mathrm{H}, \mathrm{H}_{\mathrm{e}}\right), 8.01\left(\mathrm{~d}, J=5.6 \mathrm{~Hz}, 1 \mathrm{H}, \mathrm{H}_{\text {bipy }}\right), 7.98\left(\mathrm{~d}, J=5.7 \mathrm{~Hz}, 1 \mathrm{H}, \mathrm{H}_{\text {bipy }}\right), 7.88$ $\left(\mathrm{d}, J=1.7 \mathrm{~Hz}, 1 \mathrm{H}, \mathrm{H}_{\mathrm{c}^{\prime}}\right), 7.85\left(\mathrm{dd}, J=8.2,1.8 \mathrm{~Hz}, 1 \mathrm{H}, \mathrm{H}_{\mathrm{d}^{\prime}}\right), 7.76\left(\mathrm{~d}, J=1.8 \mathrm{~Hz}, 1 \mathrm{H}, \mathrm{H}_{\mathrm{c}}\right), 7.70(\mathrm{dd}, J=7.6$, $\left.5.6 \mathrm{~Hz}, 1 \mathrm{H}, \mathrm{H}_{\text {bipy }}\right), 7.66-7.50\left(\mathrm{~m}, 7 \mathrm{H}, \mathrm{H}_{\text {bipy }}\right), 7.15\left(\mathrm{dd}, J=8.4,1.9 \mathrm{~Hz}, 1 \mathrm{H}, \mathrm{H}_{\mathrm{d}}\right), 4.50\left(\mathrm{t}, J=7.2 \mathrm{~Hz}, 4 \mathrm{H}, \mathrm{H}_{\mathrm{g}}\right)$, 4.48-4.40 (m, 4H, $\left.\mathrm{H}_{\mathrm{b}}\right), 4.38\left(\mathrm{~m}, 4 \mathrm{H}, \mathrm{H}_{\mathrm{a}}\right), 1.88\left(\mathrm{~m}, 4 \mathrm{H}, \mathrm{H}_{\mathrm{h}}\right), 1.26-1.08\left(\mathrm{~m}, 12 \mathrm{H}, \mathrm{H}_{\mathrm{i}}, \mathrm{H}_{\mathrm{j}}\right.$, and $\left.\mathrm{H}_{\mathrm{k}}\right), 0.84-0.76$ $\left(\mathrm{m}, 6 \mathrm{H}, \mathrm{H}_{1}\right)$; Compound solubility insufficient for adequate ${ }^{13} \mathrm{C}$ NMR collection; IR (ATR): $v\left(\mathrm{~cm}^{-1}\right)$ 3115, 2930, 2862, 2212, 1603, 1465, 1445, 1240, 1052, 1032, 765; HR-ESI MS: (MeOH) m/ $z=845.6856$ (calc. for $\mathrm{C}_{80} \mathrm{H}_{74} \mathrm{FeN}_{16} \mathrm{~B}_{2} \mathrm{~F}_{8}{ }^{2+} 845.6910$ ), 1778.3752 (calc. for $\mathrm{C}_{80} \mathrm{H}_{74} \mathrm{FeN}_{16} \mathrm{~B}_{3} \mathrm{~F}_{12}{ }^{+}$1778.3861); UV-Vis $\left(\mathrm{CH}_{2} \mathrm{Cl}_{2}\right)$ $\lambda_{\max }\left(\varepsilon / 10^{3} \mathrm{~L} \mathrm{~mol}^{-1} \mathrm{~cm}^{-1}\right) 288$ (137), 422 (24), 443 (1); Anal. calc. for $\mathrm{C}_{80} \mathrm{H}_{74} \mathrm{FeN}_{16} \mathrm{~B}_{4} \mathrm{~F}_{16} \cdot 3.5 \mathrm{H}_{2} \mathrm{O} \mathrm{C}$, 49.84; H, 4.23; N, 11.62\%. Found C, 49.61; H, 3.87; N, $11.43 \%$.

Synthesis of $\left[\mathbf{L} 4\left(\mathbf{R u}\left(\text { bipy }_{2}\right)_{2}\right]\left(\mathrm{BF}_{4}\right)_{4}\right.$ : Following the general procedure with: $30.9 \mathrm{mg}(0.064 \mathrm{mmol})$ of [Ru(bipy) $\left.{ }_{2} \mathrm{Cl}_{2}\right], 24.8 \mathrm{mg}(0.127 \mathrm{mmol})$ of $\left[\mathrm{AgBF}_{4}\right]$, and $20.0 \mathrm{mg}(0.029 \mathrm{mmol})$ of $\mathbf{L} 4$. The product was obtained as an orange powder. Yield: $40 \mathrm{mg}\left(74 \%\right.$, based on L4). ${ }^{1} \mathrm{H} \mathrm{NMR} \mathrm{(400} \mathrm{MHz,} d_{6}$-acetone) $\delta$ $9.26\left(\mathrm{~s}, 2 \mathrm{H}, \mathrm{H}_{\mathrm{f}}\right), 8.88-8.74\left(\mathrm{~m}, 8 \mathrm{H}, \mathrm{H}_{\text {bipy }}\right), 8.51\left(\mathrm{~d}, J=8.7 \mathrm{~Hz}, 2 \mathrm{H}, \mathrm{H}_{\mathrm{e}}\right), 8.38\left(\mathrm{~d}, J=5.6 \mathrm{~Hz}, 2 \mathrm{H}, \mathrm{H}_{\text {bipy }}\right)$, $8.23\left(\mathrm{~m}, 10 \mathrm{H}, \mathrm{H}_{\mathrm{d}}\right.$ and $\left.\mathrm{H}_{\text {bipy }}\right), 8.16\left(\mathrm{~d}, \mathrm{~J}=5.7 \mathrm{~Hz}, 2 \mathrm{H}, \mathrm{H}_{\text {bipy }}\right), 8.07\left(\mathrm{~d}, \mathrm{~J}=2.4 \mathrm{~Hz}, 2 \mathrm{H}, \mathrm{H}_{\mathrm{c}}\right), 8.04(\mathrm{~d}$, $\left.J=5.6 \mathrm{~Hz}, 2 \mathrm{H}, \mathrm{H}_{\text {bipy }}\right), 7.96\left(\mathrm{~d}, J=5.6 \mathrm{~Hz}, 2 \mathrm{H}, \mathrm{H}_{\text {bipy }}\right), 7.66-7.58\left(\mathrm{~m}, 6 \mathrm{H}, \mathrm{H}_{\text {bipy }}\right), 7.55(\mathrm{t}, J=6.8 \mathrm{~Hz}, 2 \mathrm{H}$, $\left.\mathrm{H}_{\text {bipy }}\right), 4.52-4.44\left(\mathrm{~m}, 4 \mathrm{H}, \mathrm{H}_{\mathrm{b}}\right), 4.40\left(\mathrm{~s}, 4 \mathrm{H}, \mathrm{H}_{\mathrm{a}}\right), 2.75-2.69\left(\mathrm{~m}, 4 \mathrm{H}, \mathrm{H}_{\mathrm{g}}\right), 1.63\left(\mathrm{~d}, J=8.7 \mathrm{~Hz}, 4 \mathrm{H}, \mathrm{H}_{\mathrm{h}}\right), 1.25$ $\left(\mathrm{m}, 12 \mathrm{H}, \mathrm{H}_{\mathrm{i}}, \mathrm{H}_{\mathrm{j}}\right.$, and $\left.\mathrm{H}_{\mathrm{k}}\right), 0.89-0.79\left(\mathrm{~m}, 6 \mathrm{H}, \mathrm{H}_{\mathrm{l}}\right)$; Compound solubility insufficient for adequate ${ }^{13} \mathrm{C}$ NMR collection; IR (ATR): $v\left(\mathrm{~cm}^{-1}\right)$ 3119, 2928, 2859, 2210, 1604, 1504, 1466, 1446, 1054, 1031, 765; HR-ESI MS: $(\mathrm{MeOH}) \mathrm{m} / z=845.6841$ (calc. for $\mathrm{C}_{80} \mathrm{H}_{74} \mathrm{FeN}_{16} \mathrm{~B}_{2} \mathrm{~F}_{8}{ }^{2+} 745.6910$ ), 1778.3734 (calc. for $\mathrm{C}_{80} \mathrm{H}_{74} \mathrm{FeN}_{16} \mathrm{~B}_{3} \mathrm{~F}_{12}{ }^{+}$1778.3861); UV-Vis $\left(\mathrm{CH}_{2} \mathrm{Cl}_{2}\right) \lambda_{\max }\left(\varepsilon / 10^{3} \mathrm{~L} \mathrm{~mol}^{-1} \mathrm{~cm}^{-1}\right) 285$ (148), 427 (26); Anal. calc. for $\mathrm{C}_{80} \mathrm{H}_{74} \mathrm{FeN}_{16} \mathrm{~B}_{4} \mathrm{~F}_{16} \cdot 5 \mathrm{H}_{2} \mathrm{O}$ C, 49.15; H, 4.33; N, 11.46\%. Found C, 49.01; H, 4.07; N, $11.59 \%$.

All cyclic voltammetry $(\mathrm{CV})$ experiments were performed in solutions at $20{ }^{\circ} \mathrm{C}(\mathrm{DCM})$ with a concentration of $1 \mathrm{mM}$ of electroactive analyte and $0.1 \mathrm{M} \mathrm{NBu}_{4} \mathrm{PF}_{6}$ as the supporting electrolyte. A three-electrode cell was used with Cypress Systems $1.4 \mathrm{~mm}$ diameter glassy carbon working, $\mathrm{Ag} / \mathrm{AgCl}$ reference and platinum wire auxiliary electrodes. Voltammograms were recorded with the aid of a Powerlab/4sp computer-controlled potentiostat (AD instruments, Castle Hill, NSW, Australia). Potentials for all complexes were referenced to the reversible formal potential (taken as $\mathrm{E}^{\circ}=0.00 \mathrm{~V}$ ) of the $\left[\mathrm{FC}^{*}\right]^{+/ 0}$ redox couple of decamethylferrocene [71]. In the cases of L1-L4, scans between $-2.0 \mathrm{~V}$ and $1.7 \mathrm{~V}$ revealed no processes other than the ferrocenyl oxidation.

All photochemical experiments were carried out in a custom built UV photochemical reactor (at the University of Otago, Dunedin, NZ, USA), containing four UV-C lamps (Rayonet RPR-2537A, Southern New England Ultraviolet Co., Branford, CT, USA) emitting monochromatic 254 nm radiation, arranged symmetrically around the perimeter of the photoreactor. Samples were suspended in the centre of the UV-bulb arrangement, and an in-built fan was used to maintain a constant temperature of $35{ }^{\circ} \mathrm{C}$ during irradiation experiments. 
Supplementary Materials: The following are available online. Full experimental data of all the synthetic intermediates in the synthesis of $\mathbf{L} 2$ and L4. Additionally, ${ }^{1} \mathrm{H}$ and ${ }^{13} \mathrm{C}$ NMR, ESI-MS, and UV-visible spectral data, $\mathrm{CV}$ and DPV plots, and X-ray crystallographic data for the compounds are provided. The computational methods are also detailed.

Author Contributions: Conceptualisation, J.D.C.; all synthesis and data collection, J.A.F.; Computations, J.E.B. and K.C.G.; Writing-Original Draft Preparation, J.A.F. and J.D.C.; Writing-Review and Editing, J.D.C.; J.E.B.; K.C.G. and J.A.F.

Funding: The authors wish to thank the University of Otago for funding. J.D.C. thanks the MacDiarmid Institute for Advanced Materials and Nanotechnology for additional financial support.

Acknowledgments: J.A.F. acknowledges the University of Otago for a PhD scholarship.

Conflicts of Interest: The authors declare no conflict of interest.

\section{References}

1. Kay, E.R.; Leigh, D.A. Rise of the molecular machines. Angew. Chem. Int. Ed. 2015, 54, 10080-10088. [CrossRef] [PubMed]

2. Pezzato, C.; Cheng, C.; Stoddart, J.F.; Astumian, R.D. Mastering the non-equilibrium assembly and operation of molecular machines. Chem. Soc. Rev. 2017, 46, 5491-5507. [CrossRef] [PubMed]

3. Cheng, C.; Stoddart, J.F. Wholly synthetic molecular machines. Chem. Phys. Chem. 2016, 17, 1780-1793. [CrossRef] [PubMed]

4. Richards, V. Molecular machines. Nat. Chem. 2016, 8, 1090. [CrossRef] [PubMed]

5. Feringa, B.L. The art of building small: From molecular switches to motors (Nobel lecture). Angew. Chem. Int. Ed. 2017, 56, 11060-11078. [CrossRef] [PubMed]

6. Findlay, J.A.; Crowley, J.D. Functional nanomachines: Recent advances in synthetic molecular machinery. Tetrahedron Lett. 2018, 59, 334-346. [CrossRef]

7. Erbas-Cakmak, S.; Fielden, S.D.P.; Karaca, U.; Leigh, D.A.; McTernan, C.T.; Tetlow, D.J.; Wilson, M.R. Rotary and linear molecular motors driven by pulses of a chemical fuel. Science 2017, 358, 340-343. [CrossRef] [PubMed]

8. Wilson, M.R.; Solà, J.; Carlone, A.; Goldup, S.M.; Lebrasseur, N.; Leigh, D.A. An autonomous chemically fuelled small-molecule motor. Nature 2016, 534, 235-240. [CrossRef] [PubMed]

9. Ogi, S.; Ikeda, T.; Wakabayashi, R.; Shinkai, S.; Takeuchi, M. A bevel-gear-shaped rotor bearing a double-decker porphyrin complex. Chem. Eur. J. 2010, 16, 8285-8290. [CrossRef] [PubMed]

10. Durot, S.; Reviriego, F.; Sauvage, J.-P. Copper-complexed catenanes and rotaxanes in motion: 15 years of molecular machines. Dalton Trans. 2010, 39, 10557-10570. [CrossRef] [PubMed]

11. Nygaard, S.; Laursen, B.W.; Flood, A.H.; Hansen, C.N.; Jeppesen, J.O.; Stoddart, J.F. Quantifying the working stroke of tetrathiafulvalene-based electrochemically-driven linear motor-molecules. Chem. Commun. 2006, 144-146. [CrossRef] [PubMed]

12. Le Poul, N.; Colasson, B. Electrochemically and chemically induced redox processes in molecular machines. ChemElectroChem 2015, 2, 475-496. [CrossRef]

13. Saha, S.; Stoddart, J.F. Photo-driven molecular devices. Chem. Soc. Rev. 2007, 36, 77-92. [CrossRef] [PubMed]

14. Balzani, V.; Bergamini, G.; Ceroni, P. From the photochemistry of coordination compounds to light-powered nanoscale devices and machines. Coord. Chem. Rev. 2008, 252, 2456-2469. [CrossRef]

15. Ceroni, P.; Credi, A.; Venturi, M. Light to investigate (read) and operate (write) molecular devices and machines. Chem. Soc. Rev. 2014, 43, 4068-4083. [CrossRef] [PubMed]

16. Irie, M.; Fukaminato, T.; Matsuda, K.; Kobatake, S. Photochromism of diarylethene molecules and crystals: Memories, switches and actuators. Chem. Rev. 2014, 114, 12174-12277. [CrossRef] [PubMed]

17. Bléger, D.; Hecht, S. Visible-light-activated molecular switches. Angew. Chem. Int. Ed. 2015, 54, 11338-11349. [CrossRef] [PubMed]

18. Díaz-Moscoso, A.; Ballester, P. Light-responsive molecular containers. Chem. Commun. 2017, 53, 4635-4652. [CrossRef] [PubMed]

19. Tron, A.; Jacquot de Rouville, H.-P.; Ducrot, A.; Tucker, J.H.R.; Baroncini, M.; Credi, A.; McClenaghan, N.D. Photodriven [2]rotaxane-[2] catenane interconversion. Chem. Commun. 2015, 51, 2810-2813. [CrossRef] [PubMed] 
20. Tron, A.; Thornton, P.J.; Lincheneau, C.; Desvergne, J.-P.; Spencer, N.; Tucker, J.H.R.; McClenaghan, N.D. Reversible photocapture of a [2]rotaxane harnessing a barbiturate template. J. Org. Chem. 2015, 80, 988-996. [CrossRef] [PubMed]

21. Tron, A.; Pianet, I.; Martinez-Cuezva, A.; Tucker, J.H.R.; Pisciottani, L.; Alajarin, M.; Berna, J.; McClenaghan, N.D. Remote photoregulated ring gliding in a [2]rotaxane via a molecular effector. Org. Lett. 2017, 19, 154-157. [CrossRef] [PubMed]

22. Koumura, N.; Zijlstra, R.W.J.; van Delden, R.A.; Harada, N.; Feringa, B.L. Light-driven monodirectional molecular rotor. Nature 1999, 401, 152-155. [CrossRef] [PubMed]

23. Ter Wiel, M.K.J.; van Delden, R.A.; Meetsma, A.; Feringa, B.L. Light-driven molecular motors: Stepwise thermal helix inversion during unidirectional rotation of sterically overcrowded biphenanthrylidenes. J. Am. Chem. Soc. 2005, 127, 14208-14222. [CrossRef] [PubMed]

24. Kazaryan, A.; Kistemaker, J.C.M.; Schäfer, L.V.; Browne, W.R.; Feringa, B.L.; Filatov, M. Understanding the dynamics behind the photoisomerization of a light-driven fluorene molecular rotary motor. J. Phys. Chem. A 2010, 114, 5058-5067. [CrossRef] [PubMed]

25. Kistemaker, J.C.M.; Štacko, P.; Roke, D.; Wolters, A.T.; Heideman, G.H.; Chang, M.-C.; van der Meulen, P.; Visser, J.; Otten, E.; Feringa, B.L. Third-generation light-driven symmetric molecular motors. J. Am. Chem. Soc. 2017, 139, 9650-9661. [CrossRef] [PubMed]

26. Credi, A.; Silvi, S.; Venturi, M. Light-operated machines based on threaded molecular structures. In Molecular Machines and Motors: Recent Advances and Perspectives; Credi, A., Silvi, S., Venturi, M., Eds.; Springer International Publishing: Cham, Switzerland, 2014; pp. 1-34.

27. Berná, J.; Leigh, D.A.; Lubomska, M.; Mendoza, S.M.; Pérez, E.M.; Rudolf, P.; Teobaldi, G.; Zerbetto, F. Macroscopic transport by synthetic molecular machines. Nat. Mater. 2005, 4, 704-710. [CrossRef] [PubMed]

28. Jeong, K.-S.; Chang, K.-J.; An, Y.-J. A pseudorotaxane-based molecular machine controlled by light and thermal stimuli. Chem. Commun. 2003, 1450-1451. [CrossRef]

29. Colasson, B.; Credi, A.; Ragazzon, G. Light-driven molecular machines based on ruthenium(II) polypyridine complexes: Strategies and recent advances. Coord. Chem. Rev. 2016, 325, 125-134. [CrossRef]

30. Armaroli, N.; Balzani, V.; Collin, J.-P.; Gaviña, P.; Sauvage, J.-P.; Ventura, B. Rotaxanes incorporating two different coordinating units in their thread: Synthesis and electrochemically and photochemically induced molecular motions. J. Am. Chem. Soc. 1999, 121, 4397-4408. [CrossRef]

31. Livoreil, A.; Sauvage, J.-P.; Armaroli, N.; Balzani, V.; Flamigni, L.; Ventura, B. Electrochemically and photochemically driven ring motions in a disymmetrical copper [2]-catenate. J. Am. Chem. Soc. 1997, 119, 12114-12124. [CrossRef] [PubMed]

32. Laemmel, A.C.; Collin, J.P.; Sauvage, J.P. Efficient and selective photochemical labilization of a given bidentate ligand in mixed ruthenium(II) complexes of the $\mathrm{Ru}(\text { phen })_{2} \mathrm{~L}^{2+}$ and $\mathrm{Ru}\left(\right.$ bipy ${ }_{2} \mathrm{~L}^{2+}$ family $(\mathrm{L}=$ sterically hindering chelate). Eur. J. Inorg. Chem. 1999, 1999, 383-386. [CrossRef]

33. Collin, J.-P.; Laemmel, A.-C.; Sauvage, J.-P. Photochemical expulsion of a $\mathrm{Ru}(\mathrm{phen})_{2}$ unit from a macrocyclic receptor and its thermal recoordination. New J. Chem. 2001, 25, 22-24. [CrossRef]

34. Mobian, P.; Kern, J.-M.; Sauvage, J.-P. Light-driven machine prototypes based on dissociative excited states: Photoinduced decoordination and thermal recoordination of a ring in a ruthenium(I)-containing [2]catenane. Angew. Chem. Int. Ed. 2004, 43, 2392-2395. [CrossRef] [PubMed]

35. Collin, J.-P.; Jouvenot, D.; Koizumi, M.; Sauvage, J.-P. A ruthenium(II)-complexed rotaxane whose ring incorporates a 6,6'-diphenyl-2,2'-bipyridine: Synthesis and light-driven motions. Eur. J. Inorg. Chem. 2005, 2005, 1850-1855. [CrossRef]

36. Scattergood, P.A.; Ross, D.A.W.; Rice, C.R.; Elliott, P.I.P. Labilizing the photoinert: Extraordinarily facile photochemical ligand ejection in an $\left[\mathrm{Os}\left(\mathrm{N}^{\wedge} \mathrm{N}\right)_{3}\right]^{2+}$ complex. Angew. Chem. Int. Ed. 2016, 55, 10697-10701. [CrossRef] [PubMed]

37. Wei, J.; Renfrew, A.K. Photolabile ruthenium complexes to cage and release a highly cytotoxic anticancer agent. J. Inorg. Biochem. 2018, 179, 146-153. [CrossRef] [PubMed]

38. Havrylyuk, D.; Heidary, D.K.; Nease, L.; Parkin, S.; Glazer, E.C. Photochemical properties and structure-Activity relationships of $\mathrm{Ru}(\mathrm{II})$ complexes with pyridylbenzazole ligands as promising anticancer agents. Eur. J. Inorg. Chem. 2017, 2017, 1687-1694. [CrossRef] [PubMed]

39. Wachter, E.; Moyá, D.; Parkin, S.; Glazer, E.C. Ruthenium complex "light switches" that are selective for different g-quadruplex structures. Chem. Eur. J. 2016, 22, 550-559. [CrossRef] [PubMed] 
40. Kohler, L.; Nease, L.; Vo, P.; Garofolo, J.; Heidary, D.K.; Thummel, R.P.; Glazer, E.C. Photochemical and photobiological activity of $\mathrm{Ru}(\mathrm{II})$ homoleptic and heteroleptic complexes containing methylated bipyridyl-type ligands. Inorg. Chem. 2017, 56, 12214-12223. [CrossRef] [PubMed]

41. Abreu, F.D.; Paulo, T.D.F.; Gehlen, M.H.; Ando, R.A.; Lopes, L.G.F.; Gondim, A.C.S.; Vasconcelos, M.A.; Teixeira, E.H.; Sousa, E.H.S.; de Carvalho, I.M.M. Aryl-substituted ruthenium(II) complexes: A strategy for enhanced photocleavage and efficient DNA binding. Inorg. Chem. 2017, 56, 9084-9096. [CrossRef] [PubMed]

42. Liu, J.; Zhang, C.; Rees, T.W.; Ke, L.; Ji, L.; Chao, H. Harnessing ruthenium(II) as photodynamic agents: Encouraging advances in cancer therapy. Coord. Chem. Rev. 2018, 363, 17-28. [CrossRef]

43. Alfredo, N.V.; Jalapa, N.E.; Morales, S.L.; Ryabov, A.D.; Le Lagadec, R.; Alexandrova, L. Light-driven living/controlled radical polymerization of hydrophobic monomers catalyzed by ruthenium(II) metallacycles. Macromolecules 2012, 45, 8135-8146. [CrossRef]

44. Laramée-Milette, B.; Nastasi, F.; Puntoriero, F.; Campagna, S.; Hanan, G.S. Cover feature: Photo-induced assembly of a luminescent tetraruthenium square. Chem. Eur. J. 2017, 23, 16410. [CrossRef]

45. Bonnet, S.; Collin, J.-P. Ruthenium-based light-driven molecular machine prototypes: Synthesis and properties. Chem. Soc. Rev. 2008, 37, 1207-1217. [CrossRef] [PubMed]

46. Collin, J.-P.; Jouvenot, D.; Koizumi, M.; Sauvage, J.-P. Light-driven expulsion of the sterically hindering ligand $\mathrm{L}$ in tris-diimine ruthenium(II) complexes of the $\mathrm{Ru}(\text { phen })_{2}(\mathrm{~L})^{2+}$ family: A pronounced ring effect. Inorg. Chem. 2005, 44, 4693-4698. [CrossRef] [PubMed]

47. Hammarström, L.; Alsins, J.; Börje, A.; Norrby, T.; Zhang, L.; Åkermark, B. Structure and photophysical properties of novel ruthenium(II) complexes containing 6-substituted bipyridines. J. Photochem. Photobiol. A 1997, 102, 139-150. [CrossRef]

48. Welby, C.E.; Armitage, G.K.; Bartley, H.; Sinopoli, A.; Uppal, B.S.; Elliott, P.I.P. Photochemical ligand ejection from non-sterically promoted $\mathrm{Ru}(\mathrm{II})$ bis (diimine) 4,4'-bi-1,2,3-triazolyl complexes. Photochem. Photobiol. Sci. 2014, 13, 735-738. [CrossRef] [PubMed]

49. Lo, W.K.C.; Huff, G.S.; Cubanski, J.R.; Kennedy, A.D.W.; McAdam, C.J.; McMorran, D.A.; Gordon, K.C.; Crowley, J.D. Comparison of inverse and regular 2-pyridyl-1,2,3-triazole "click" complexes: Structures, stability, electrochemical, and photophysical properties. Inorg. Chem. 2015, 54, 1572-1587. [CrossRef] [PubMed]

50. Hohloch, S.; Schweinfurth, D.; Sommer, M.G.; Weisser, F.; Deibel, N.; Ehret, F.; Sarkar, B. The redox series $\left[\mathrm{Ru}(\mathrm{bpy})_{2}(\mathrm{~L})\right]^{n}, n=+3,+2,+1,0$, with $\mathrm{L}=$ bipyridine, "click" derived pyridyl-triazole or bis-triazole: A combined structural, electrochemical, spectroelectrochemical and DFT investigation. Dalton Trans. 2014, 43, 4437-4450. [CrossRef] [PubMed]

51. Dixon, I.M.; Heully, J.-L.; Alary, F.; Elliott, P.I.P. Theoretical illumination of highly original photoreactive ${ }^{3} \mathrm{MC}$ states and the mechanism of the photochemistry of Ru(II) tris(bidentate) complexes. Phys. Chem. Chem. Phys. 2017, 19, 27765-27778. [CrossRef] [PubMed]

52. Takada, K.; Miyazaki, T.; Tanaka, N.; Tatsuma, T. Three-dimensional motion and transformation of a photoelectrochemical actuator. Chem. Commun. 2006, 2024-2026. [CrossRef] [PubMed]

53. Li, Q.; Fuks, G.; Moulin, E.; Maaloum, M.; Rawiso, M.; Kulic, I.; Foy, J.T.; Giuseppone, N. Macroscopic contraction of a gel induced by the integrated motion of light-driven molecular motors. Nat. Nanotechnol. 2015, 10, 161-165. [CrossRef] [PubMed]

54. Foy, J.T.; Li, Q.; Goujon, A.; Colard-Itté, J.-R.; Fuks, G.; Moulin, E.; Schiffmann, O.; Dattler, D.; Funeriu, D.P.; Giuseppone, N. Dual-light control of nanomachines that integrate motor and modulator subunits. Nat. Nanotechnol. 2017, 12, 540-545. [CrossRef] [PubMed]

55. Lee, C.-L.; Liebig, T.; Hecht, S.; Bléger, D.; Rabe, J.P. Light-induced contraction and extension of single macromolecules on a modified graphite surface. ACS Nano 2014, 8, 11987-11993. [CrossRef] [PubMed]

56. Wang, X.-B.; Dai, B.; Woo, H.-K.; Wang, L.-S. Intramolecular rotation through proton transfer: $\left[\mathrm{Fe}\left(\eta^{5}-\mathrm{C}_{5} \mathrm{H}_{4} \mathrm{CO}_{2}{ }^{-}\right)_{2}\right]$ versus $\left[\left(\eta^{5}-\mathrm{C}_{5} \mathrm{H}_{4} \mathrm{CO}_{2}{ }^{-}\right) \mathrm{Fe}\left(\eta^{5}-\mathrm{C}_{5} \mathrm{H}_{4} \mathrm{CO}_{2} \mathrm{H}\right)\right]$. Angew. Chem. Int. Ed. 2005, 44, 6022-6024. [CrossRef] [PubMed]

57. Pisciottani, L.; Douarre, M.; Bibal, B.; Davies, C.; Roberts, H.; Kauffmann, B.; Horswell, S.L.; Tucker, J.H.R.; McClenaghan, N.D. Macrocyclic hamilton-type receptors comprising a ferrocene pivot. Supramol. Chem. 2018, 30, 869-875. [CrossRef]

58. Heinze, K.; Schlenker, M. Anion-induced motion in a ferrocene diamide. Eur. J. Inorg. Chem. 2005, 2005, 66-71. [CrossRef] 
59. Takai, A.; Yasuda, T.; Ishizuka, T.; Kojima, T.; Takeuchi, M. A directly linked ferrocene-naphthalenediimide conjugate: Precise control of stacking structures of $\pi$-systems by redox stimuli. Angew. Chem. Int. Ed. 2013, 52, 9167-9171. [CrossRef] [PubMed]

60. Iordache, A.; Oltean, M.; Milet, A.; Thomas, F.; Baptiste, B.; Saint-Aman, E.; Bucher, C. Redox control of rotary motions in ferrocene-based elemental ball bearings. J. Am. Chem. Soc. 2012, 134, 2653-2671. [CrossRef] [PubMed]

61. Scottwell, S.O.; Elliott, A.B.S.; Shaffer, K.J.; Nafady, A.; McAdam, C.J.; Gordon, K.C.; Crowley, J.D. Chemically and electrochemically induced expansion and contraction of a ferrocene rotor. Chem. Commun. 2015, 51, 8161-8164. [CrossRef] [PubMed]

62. Scottwell, S.O.; Barnsley, J.E.; McAdam, C.J.; Gordon, K.C.; Crowley, J.D. A ferrocene based switchable molecular folding ruler. Chem. Commun. 2017, 53, 7628-7631. [CrossRef] [PubMed]

63. Collin, J.-P.; Gavinã, P.; Sauvage, J.-P. Electrochemically induced molecular motions in a copper(I) complex pseudorotaxane. Chem. Commun. 1996, 2005-2006. [CrossRef]

64. Collin, J.-P.; Gavina, P.; Sauvage, J.-P. Electrochemically induced molecular motions in copper-complexed threaded systems: From the unstoppered compound to the semi-rotaxane and the fully blocked rotaxane. New J. Chem. 1997, 21, 525-528.

65. Schmittel, M.; Ganz, A.; Schenk, W.A.; Hagel, M. Synthesis and coordination properties of 6,6'-dimesityl-2,2'-bipyridine. Z. Naturforsch. B 1999, 54, 559-564. [CrossRef]

66. Schmittel, M.; He, B.; Fan, J.; Bats, J.W.; Engeser, M.; Schlosser, M.; Deiseroth, H.-J. Cap for copper(I) ions! Metallosupramolecular solid and solution state structures on the basis of the dynamic tetrahedral $\left[\mathrm{Cu}\left(\text { phenar }_{2}\right)(\text { py })_{2}\right]^{+}$motif. Inorg. Chem. 2009, 48, 8192-8200. [CrossRef] [PubMed]

67. Findlay, J.A.; McAdam, C.J.; Sutton, J.J.; Preston, D.; Gordon, K.C.; Crowley, J.D. Metallosupramolecular architectures formed with ferrocene-linked bis-bidentate ligands: Synthesis, structures, and electrochemical studies. Inorg. Chem. 2018, 57, 3602-3614. [CrossRef] [PubMed]

68. Nakamoto, K. Ultraviolet spectra and structures of 2,2'-bipyridine and $2,2^{\prime}, 2^{\prime \prime}$-terpyridine in aqueous solution. J. Phys. Chem. 1960, 64, 1420-1425. [CrossRef]

69. Bozak, R.E. Photochemistry in the metallocenes. In Advances in Photochemistry; John Wiley \& Sons, Inc.: Hoboken, NJ, USA, 1971; pp. 227-244.

70. Inkpen, M.S.; Du, S.; Driver, M.; Albrecht, T.; Long, N.J. Oxidative purification of halogenated ferrocenes. Dalton Trans. 2013, 42, 2813-2816. [CrossRef] [PubMed]

71. Noviandri, I.; Brown, K.N.; Fleming, D.S.; Gulyas, P.T.; Lay, P.A.; Masters, A.F.; Phillips, L. The decamethylferrocenium/decamethylferrocene redox couple: A superior redox standard to the ferrocenium/ferrocene redox couple for studying solvent effects on the thermodynamics of electron transfer. J. Phys. Chem. B 1999, 103, 6713-6722. [CrossRef]

Sample Availability: Samples of the compounds are available from the authors upon request.

(C) 2018 by the authors. Licensee MDPI, Basel, Switzerland. This article is an open access article distributed under the terms and conditions of the Creative Commons Attribution (CC BY) license (http:/ / creativecommons.org/licenses/by/4.0/). 